\title{
Substitute Arguments in Constitutional Law
}

Louis Michael Seidman

Georgetown University Law Center, seidman@law.georgetown.edu

This paper can be downloaded free of charge from:

https://scholarship.law.georgetown.edu/facpub/1497

http://ssrn.com/abstract=2631119

This open-access article is brought to you by the Georgetown Law Library. Posted with permission of the author. Follow this and additional works at: https://scholarship.law.georgetown.edu/facpub

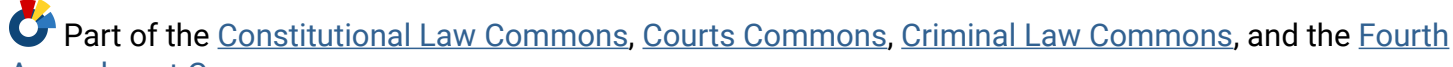




\section{Substitute Arguments in Constitutional Law}

\section{Louis Michael Seidman*}

In United States v. Watson ${ }^{1}$ the Supreme Court held that the fourth amendment did not require the police to obtain a warrant when arresting a suspected felon in a public place. Writing for the majority, Justice Byron White relied in large part on the fact that the authors of the fourth amendment apparently did not intend to disavow "the ancient common-law rule that a peace officer was permitted to arrest without a warrant for a . . felony not committed in his presence if there was reasonable ground for making the arrest." 2

In his dissenting opinion, Justice Thurgood Marshall attacked this argument. The common law rule applied to felonies but not misdemeanors and, Marshall pointed out, the meaning of these categories had changed over time. At the time of the framing, all felonies were punishable by death. This was because "only the most serious crimes were felonies ... and many crimes now classified as felonies under federal or state law were treated as misdemeanors." ${ }^{3}$ True, the common law rule required arrest warrants only for misdemeanors not committed in the officer's presence but, on Marshall's view, translating the framer's intent into the modern context meant requiring arrest warrants for the kind of crimes that were classified as misdemeanors at the time of the framing but are now considered felonies.

\footnotetext{
* Carmack Waterhouse Professor of Constitutional Law, Georgetown University Law Center

I am grateful to William Baude, Jessica Bulman-Pozen, Mary Anne Case, Jianlin Chen, Zachary Clopton, Ryan Doerfler, Justin Driver, Irving Gornstein, Amanda Greene, Aziz Huq, Issa Kohler-Haussmann, Todd Henderson, Eric Posner, Alison LaCroix, Genevieve Lakier, Richard McAdams, Allegra McLeod, Girardeau Spann, Geoffrey Stone, David Strauss, Peter Tague, Laura Weinrib, and participants at workshops at Northwestern University Law School and The University of Chicago Law School for helpful comments. I was greatly helped by superb research assistance from Deepa Das Acevedo and Marc Gersen.

1423 U.S. 411 (1976).

$2 \quad$ Id. at 418 .

3 Id. at 439-40 (Marshall, J., dissenting).
} 
Taken at face value, this dispute presents interesting and pervasive theoretical questions about how to give effect to old legal language when the underlying context has shifted. ${ }^{4}$ But should we take it at face value?

Justice White did not respond to Justice Marshall's argument in Watson, but Watson was not the last case in which White encountered the argument. Nine years later, White again wrote for the Court on the intersection between the fourth amendment and the arrest power. In Tennessee $v$.

Garner, ${ }^{5}$ the issue was whether the fourth amendment put limits on the use of deadly force to arrest a suspected felon. In holding that there were such limits, White had to confront the government's contention that "the Fourth Amendment must be construed in light of the common-law rule, which allowed the use of whatever force was necessary to effect the arrest of a fleeing felon, though not a misdemeanant." 6

In response, Justice White conceded that his own opinion in Watson supported the proposition that "this Court has often looked to the common law in evaluating the reasonableness, for Fourth Amendment purposes, of police activity," ${ }^{7}$ but nowhere explained why Garner was distinguishable from

Watson. Instead, without citing Justice Marshall's Watson dissent, he wrote the following:

Because of sweeping change in the legal and technological context, reliance on the commonlaw rule in this case would be a mistaken literalism that ignores the purposes of a historical inquiry....

It has been pointed out many times that the common-law rule is best understood in light of the fact that it arose at a time when virtually all felonies were punishable by death. . . .

$4 \quad$ There is, of course, a vast literature on this subject. For an introduction, compare Lawrence Lessig, Fidelity in Translation, 71 TEX. LAW. REV. 165 (1993) with Steven G. Calabresi, The Tradition of the Written Constitution: A Comment on Professor Lessig's Theory of Translation, 65 FORD. L. REV. 1435 (1997).

$5 \quad 471$ U.S. 1 (1985).

$6 \quad$ Id. at 12.

7 Id. At 13. 
And while in earlier times "the gulf between the felonies and the minor offences was broad and deep," . . today the distinction is minor and often arbitrary. Many crimes classified as misdemeanors ... at common law are now felonies. ${ }^{8}$

The opinion is entirely silent on why this point was persuasive in Garner but so inconsequential as not to merit a response in Watson. This unadorned about-face gives rise to at least the suspicion that Justice White was making what I call in this article a substitute argument.

As used here, the term "substitute argument" refers to reasons offered in favor of an ultimate conclusion when the stated reasons substitute for what I will call authentic reasons - that is, the reasons that cause the advocate to argue for that conclusion. ${ }^{9}$ Put differently, an argument is a substitute when the advocate would not make it but for a desire to reach the conclusion for some different reason.

When advocates believe that the substitute argument is false, they use the argument hypocritically. Substitutes need not be hypocritical, however. The argument would still be a substitute even if the proponent believed that it was correct, so long as he would not be motivated to make the argument unless he favored the conclusion for different reasons. ${ }^{10}$ And it would remain a substitute even if, as often happens, he manages to convince himself that he is making the argument because he

\footnotetext{
$8 \quad$ Id. at $13-14$.

9 I intend, therefore, to adopt an internal, rather than an external account of reasons. See BERNARD WILLIAMS, MORAL LUCK: PHILOSOPHICAL PAPERS, 1973-1980 at 101 (1981). Internal reasons are reflected in the sentence "A has a reason to do $X$ " as opposed to "there is a reason for A to do $X$," which reflects an external reason. See id. On Williams' account, an internal reason statement is falsified by the absence of some appropriate element from what he calls the agent's "subjective motivational set." Id., at 102. Members of the set, in turn, can be added or subtracted through deliberation, and a member does not count if it is based upon a false belief. Id., at 103-04. So long as internal reasons are so understood, Williams doubts that there can be authentically external reasons for action. See id., at 111.

10 I mean to distinguish here between reasons for believing that a proposition is true and reasons for making a particular argument in favor of the proposition's truth. One might have the former sort of reason, yet lack an element in one's motivational set to cause one to make an argument for its truth. See note 9, supra. For an elaboration, see pp xx-xx, infra.
} 
believes in its correctness so long as he would not have convinced himself but for reasons unrelated to the argument's merits. ${ }^{11}$

The fact that in Garner Justice White advanced the very argument that he rejected in Watson suggests that the argument is a substitute. If the argument were an authentic reason for his decision in one case, one would expect that it would merit at least mention in the other. The inconsistency gives rise to a suspicion that the argument is instead a "make weight" - that it is substituting for the authentic reasons that are driving the outcomes.

To be clear, my purpose in choosing this opening example is not to single out Justice White for special criticism. On the contrary, I argue that the phenomenon of substitution is so pervasive that one could find many examples drawn from every Supreme Court Term. I choose this example both because the seeming conflict between Watson and Garner provides unusually strong evidence of substitution and because the cases are old and therefore do not implicate currently controversial disputes about the work of sitting justices.

It is often difficult to prove that substitution is going on. Even in the Watson-Garner example, where there seems to be a direct contradiction, other explanations are possible. Perhaps Justice White

11 Here and throughout this article, I put to one side one species of substitution - arguments made by the "devil's advocate." People sometimes advance ideas or arguments that they don't believe so as to test the strength of an opposing idea or argument. See, e.g., Keith Burgess-Jackson, Principled Objections and Sham Arguments: The Case of Capital Punishment, 32 PHIL. \& RHETORIC 299, 305 (1999) (noting that "[t]here is a long and reputable tradition in both law and philosophy of 'playing devil's advocate,' 'taking a position [or assuming a proposition] for the sake of argument,' and 'drawing out the implications' of some thesis, view or assumption to which one does not personally subscribe.")Devil's advocate arguments are substitutes in the sense that they are not motivated by belief in the argument's correctness. They are nonetheless distinguishable because the advocate for the argument does not desire for it to prevail - at least for so long as the person advancing the position perceives herself as the devil's advocate. Of course, the advocate might ultimately be persuaded by the argument. That, after all, is the point of advancing it. However, at the point she is persuaded, she abandons her devil's advocate role, and the argument is then no longer a substitute. 
saw a crucial difference between the two cases but for some reason did not bother to explain to his readers what it was. ${ }^{12}$ Perhaps he simply changed his mind.

But even if it is difficult to prove substitution definitively in individual cases, it is hard to shake the sense that it is an important feature of the legal landscape. ${ }^{13}$ Does anyone who knows the biographies of Justices White and Marshall actually believe that their general attitudes toward the fourth amendment turn on the meaning of the common law in 1791 as opposed to their life experiences with crime, the police, race, and government?

In this article, I argue that that substitution is crucial to our practice of constitutional law. Of course, if one wished, one could easily extend the domain of substitution beyond these boundaries. ${ }^{14}$ Substitute arguments are an important aspect of law more generally and, indeed, of life. I have nonetheless chosen to limit my discussion to constitutional substitution because, I believe, overt discussion of substitution in this particular area illuminates important aspects of our constitutional regime - aspects that substitution itself regularly obscures. To put my central point directly, I hope to show that constitutional law amounts to one, giant substitute argument.

Making that claim plausible will take some work. In this short introduction I want to make a much more modest claim. At the very least, most of us are ambivalent and confused about the legitimacy of substitute arguments. On the one hand, these arguments at least some time seem to

12 For example, perhaps one could reconcile Justice White's positions in Watson and Garner on the ground that the universal use of the death penalty in felony cases in 1789 made deadly force appropriate to arrest felons then but not now, whereas shifts in use of the death penalty have less relevance to whether a warrant is required prior to arrest. But although this distinction might explain Justice White's reference to the death penalty, it does not explain his broader point about the shifts between the felony and misdemeanor categories. Nor does it explain his failure to address the Watson dissent.

13 Cf. David E. Posen, Constitutional Bad Faith (unpublished draft on file with author) ("Constitutional law is so imbricated with politics and 'cross-cutting relational obligations' that fiduciary law's pristine conceptions of good faith, and its powerful proxies for bad faith, would wreak havoc if applied.")

14 See, e.g., Paul Krugman, "Ideology and Economics" N.Y. Times, Jan 5, 2013), http:\\krugman.blogs.nytimes.com/2013/01/05/ideology-and-economics (arguing that it poses a problem for macroeconomics if it is perceived that "influential economists choose their doctrines to suit their political prejudices.") 
violate the duty of candor we owe to each other. If I think that outcome $A$ is desirable for reason $X, I$ should say so and then let you evaluate the force of X. When I instead advance reason $\mathrm{Y}, \mathrm{I}$ am acting dishonestly if, despite what I have said to you, I may promptly abandon reason $\mathrm{Y}$ just as soon as it is no longer instrumentally useful to me. People who are caught using substitute arguments are said to be acting in bad faith, to be unprincipled, or to be "result oriented." They are seen as trying to manipulate their interlocutor, rather than having an authentic dialogue with her. ${ }^{15}$

On the other hand, most of us at least purport to believe that arguments are either persuasive or not, without regard to the character of the person offering them. One might even say that the depersonalization of argument is crucial to the rule of law. Equal treatment under law implies that legal arguments should be evaluated on their abstract merit without regard to our feelings about the people who advance them. ${ }^{16}$

Moreover, sometimes substitute arguments can bridge gaps that otherwise seem unbridgeable. The effort to explain my position in terms that you understand can build empathic connection and coalitions that otherwise might be impossible.

Finally, as I have just suggested, substitute arguments are pervasive in constitutional discourse. Because everyone knows that they are pervasive, they often fool no one. If the targets of the argument are not fooled, how are those making the arguments doing any harm and why should they be subject to moral criticism? And, conversely, if the people making the arguments are in fact widely subject to this

15 See, e.g, David L. Shapiro, Mr. Justice Rehnquist: A Preliminary View, 90 HARV. L. REV. 293, 349 (1976) ("too often, [Justice Rehnquist's] efforts to deal with prior decisions are singularly unpersuasive and leave the reader with the impression that the law is being changed without the acknowledgment that candor would demand"); Alan M. Dershowitz \& John Hart Ely, Harris v. New York: Some Anxious Observations on the Candor and Logic of the Emerging Nixon Majority, 80 YALE L. J. 1198, 1226 (1971) (“A thoughtful opinion acknowledging the value choices at issue and resolving them against the defendant would at least have been candid, though not in our view convincing. This one was neither.")

16 For the canonical statement of this position, see Herbert Wechsler, Toward Neutral Principles of Constitutional Law, 73 HARV. L. REV. 1, 19 (1959) (arguing that a principled decision "rests on reasons with respect to all issues in the case, reasons that in their generality and their neutrality transcend any immediate result that is involved.") 
criticism and widely known to be engaged in conduct that earns the criticism, why do they persist in this seemingly self-destructive behavior?

Before trying to answer these questions, we need to lay some groundwork. Part I of this Article discusses the pervasiveness of the phenomenon. As I have already mentioned, proving pervasiveness empirically is difficult because it is often impossible to know what actually motivates a legal actor. In making the case for the prevalence of substitutes, I rely in part on empirical studies that are suggestive, if not definitive, in part on what participants in constitutional practice say about themselves and about each other, and in part on the hope that the reader will share intuitions gained from immersion in contemporary legal culture.

Part II catalogues categories of substitute argument, provides a framework for thinking about them, and offers some preliminary normative assessments. Along one dimension, we can differentiate between substitute arguments based on the mental state of the person making them. The arguments can be nonmotivating, hypocritical, or unconscious. Along another dimension, we can make distinctions based on the level at which the argument is made. Substitute arguments can be specific, structural, or foundational. All substitutes are troubling, but some are relatively benign and some are even praiseworthy. Our normative judgments about substitutes varies across these categories.

Part III addresses the problem of function. What is gained by making these arguments? The question can be subdivided into two components: First, what motivates individuals to make the arguments? Often the motivation is quite apparent as when, for example, one doctrinal path to a desired outcome is blocked but another remains open. But this individual motivation does not explain our societal ambivalence about substitution. Why do we regularly embrace substitution even as we attack each other for doing so? 
To understand that contradiction, we need to investigate a second question: What kind of external account of the social function served by substitution can we provide? Building on the work of John Rawls and Cass Sunstein among others, I hope to show that substitution is fundamental to the practice of American constitutional law. It provides the mechanism by which the Constitution attempts to serve its core function -- maintaining peace in a pluralist society. Constitutional law consists of an only partially successful effort to accomplish this goal by substituting relatively anodyne disputation for the potentially explosive disagreements that actually divide us. Constitutional law just is substitution.

The concluding Part explores the possibility of a world without substitution. I argue that it is naïve to suppose that we can totally eliminate substitute arguments, but that important questions remain about more or less and better or worse. We might avoid some of the worst aspects of substitution while preserving some of the benefits if we abandoned constitutional substitutes and replaced them with arguments drawn from sources like tradition, morality, political philosophy, and practical reason.

\section{The Pervasiveness of Substitution}

How can one prove that an advocate is making a substitute argument? In this section, I mostly resist the temptation to cite examples and name names. Of course, all of us have our favorite Supreme Court decision that is explicable only if one assumes that a substitution is at work (our personal Bush v. Gores, if you will - and here, I must beg forgiveness for promptly succumbing to the very temptation that I just said I was going to resist). We all have our suspicions about law review articles that seem to have been written for a political purpose and about public figures who appear to be using constitutional argument instrumentally and hypocritically.

There are nonetheless two problems with "bottom up" empiricism based on particular and egregious examples. First, absent a massive study that it is hard to imagine anyone actually conducting, 
conclusions based on induction risk being distorted by salient but unrepresentative examples. Second, in virtually all individual cases where one might suspect substitution, the conclusion will be controversial. Two statements in different cases by the same Supreme Court justice may seem flatly contradictory, and the contradiction may seem explicable only on the assumption that the justice is motivated by unstated reasons, but lawyers and law professors make their living by inventing clever arguments to reconcile the irreconcilable (arguments that, of course, we might suspect are themselves substitutes). ${ }^{17}$ Who can be certain that such a reconciliation in a given case is merely post hoc rationalization?

Despite these problems, and perhaps somewhat unfairly, in what follows, I rely in part on what is, I hope, the reader's own intuition that substitution is very common in our constitutional culture. I supplement that intuition with what constitutional practitioners themselves say about their own and others' work and with empirical data that is suggestive but, I concede, not conclusive. ${ }^{18}$

\section{A. Practicing Lawyers}

In the case of practicing lawyers who engage in advocacy, there is little difficulty in demonstrating the prevalence of substitution because lawyers themselves tell us that they use the practice. We generallg expect people to be honest with us when they argue about issues of importance, but lawyers insist as a point of pride that they are exempt from this expectation. Lawyers often do not indeed often are not permitted to - say what they really think. Instead, they have a professional

17 See, e.g., note 12 , supra.

18 An additional problem with the evidence that I marshal below is that some of it concerns all domains of legal argument, rather than only argument about constitutional questions. It may be that substitution is a problem for law generally, but my focus in this article is on the special problem of substitute arguments in constitutional law. At least one of the studies I discuss below suggests that substitution is a more serious problem in the constitutional domain than in other areas. See $\mathrm{pp} \mathrm{xx}$, infra. There is no reason to think that instances of constitutional substitution are less frequent than other forms of substitution in the other studies that I discuss below, but I cannot prove that this is not the case. 
obligation to represent interests of their clients, ${ }^{19}$ at least within broad limits. ${ }^{20}$ Given this obligation, it only stands to reason that they regularly make substitute arguments.

To be sure, not everyone agrees with this conception of legal advocacy. ${ }^{21} \mathrm{~A}$ defense of the role morality of lawyers rests crucially on the legitimacy of the adversary system itself. If the adversary system is legitimate, then lawyers who participate in the system by advancing arguments that they, themselves, do not think justify their conclusion may also be acting legitimately. Conversely, if the system is evil, then the role that lawyers play in it may be evil as well. And even if the system itself is defensible, it does not automatically follow that lawyers are immune from criticism when they choose to spend their lives engaged in this activity as opposed to other ways that they could occupy their time.

Once out of law school, most lawyers have little time to worry about these problems except in rare situations where the conflict between their role morality and ordinary morality is too obvious to ignore. Still, even in the setting of litigation, where substitution is most defensible and commonplace, they exhibit curious remnants of doubt, ambivalence, and embarrassment about the practice.

Consider for example, the following exchange in the oral argument in King v. Burwell concerning the correct interpretation of the Affordable Care Act:

JUSTICE KAGAN: Mr. Carvin, that's not that's not what you said previously when you were here last time in this never ending saga.

19 See, e.g., AMERICAN BAR ASSOCIATION, "Preamble and Scope [9]”, MODEL RULES OF PROFESSIONAL CONDUCT ("These principles include the lawyer's obligation zealously to protect and pursue the client's legitimate interests, within the bounds of law"; id, at [2] ("As advocate, a lawyer zealously asserts the client's position under the rules of the adversary system.")

20 See id. at Rule 3.3(a) (prohibiting a lawyer from knowingly making a false statement of fact or law to a tribunal and from failing to disclose to the tribunal legal authority in a controlling jurisdiction that is adverse to the position of a client and not disclosed by opposing counsel).

${ }^{21}$ For powerful criticisms, see William Simon, The Ideology of Advocacy: Procedural Justice and Professional Ethics, 1978 WIS. L. REV. 29; DAVID LUBAN, LAWYERS AND JUSTICE: AN ETHICAL STUDY (1988). But cf. David Luban, Are Criminal Defendants Different? 91 MICH. L. REV. 1729 (1993).For canonical defenses see Charles Fried, The Lawyer as Friend: The Moral Foundations of the Lawyer-Client Relation, 85 YALE L. J. 1060 (1976); MONROE H. FREEDMAN, UNDERSTANDING LAWYERS' ETHICS (1990). 
(Laughter.)

JUSTICE KAGAN: You said without the subsidies driving demand within the Exchanges, insurance companies would have absolutely no reason to offer their products through Exchanges. And then you said the insurance Exchanges cannot operate as intended by Congress absent the subsidies....

CHIEF JUSTICE ROBERTS: Mr. Carvin, we've heard talk about this other case. Did you win that other case?

(Laughter.)

CHIEF JUSTICE ROBERTS: So maybe it makes sense that you have a different story today?

MR. CARVIN: I'm really glad Your Honor said that.

(Laughter.) 22

Chief Justice Roberts' comments suggest the conventional view that Mr. Carvin did nothing improper by making inconsistent arguments in the two cases. Yet the laughter also suggests at least mild discomfort at confronting the inconsistency. The discomfort would increase exponentially if an advocate directly confessed to making a substitute argument. Imagine that a lawyer in a major constitutional case before the United States Supreme Court started his argument with these words:

Mr. Chief Justice and may it please the Court.

Before I begin, I want to make clear that I personally disagree with the position that I am about to defend. I am making these arguments not because I believe them to be correct, but because I have been paid by my client to make them and because, as a matter of legal ethics, I am bound to make them. I personally think that the arguments are wrong, but they are not frivolous, and I can easily imagine that you will find them persuasive.

Of course, no advocate in the real world would start an oral argument this way. ${ }^{23}$ But why not? Why would the justices react negatively to this statement? ${ }^{24}$ Why doesn't the advocate have an ethical duty to reveal his honest opinion of the arguments he makes?

22 Transcript of oral argument in King v. Burwell, (2014) (No. 14-114) available at http://www.supremecourt.gov/oral_arguments/argument_transcripts/14-114_lkhn.pdf.

23 A possible exception to this generalization is the statement that regularly appears in "Anders" briefs. See Anders v. California, 386 U.S. 738 (1967). After the Supreme Court established an indigent defendant's right to 
The cultural prohibition on candid acknowledgment of substitution reflects an important paradox. On the one hand, sophisticated observers, including all the justices to whom my hypothetical advocate addresses his statement, know that they are or may be hearing substitutes not just in this case, but in every case. On the other hand, the bald admission that an argument is a substitute is not just terrible advocacy; it also violates a fundamental taboo.

Perhaps the paradox stems from the residual hold ordinary ethics has over us even in a domain controlled by decidedly out-of-the-ordinary legal ethics. Even lawyers long socialized in legal norms cannot quite shake the feeling that they are doing something wrong when they find themselves alienated from the very words that they speak. ${ }^{25}$ But although this provides a partial explanation for the paradox, I believe that there is more to it. Before exploring what this "more" consists of, however, it is important to see the ways in which substitution has metastasized to areas far beyond the realm of lawyers representing clients.

\section{B. Judges}

Consider, for example, the case of judges. In contrast to lawyers, judges have no obligation to say things that they do not believe. ${ }^{26}$ On the contrary, deeply embedded norms require judges to be

appointed counsel on an initial appeal, see Douglas v. California, 372 U.S. 358 (1963), a question arose as to the lawyer's obligations when there were no non-frivolous arguments available to attack the conviction. In Anders the Court directed the lawyer to so advise the appellate court and move to withdraw, but to accompany the request with a "brief referring to anything in the record that might arguably support the appeal." 386 U.S., at 744. The required brief in effect directs the trial court to arguments that might conceivably support a reversal while also communicating the attorney's view that the arguments are frivolous.

\footnotetext{
24 For a partial answer, see pp xx, supra.

25 See, e.g., Mathilde Cohen, Sincerity and Reason-Giving: When May Legal Decision Makers Lie, 59 DEPAUL L. REV. 1091, 1110 (2010) (arguing that "giving insincere reasons is intrinsically wrong because it harms people's autonomy".)

${ }^{26}$ Of course, a judge might feel obligated to follow precedent or a higher court decision that he believes incorrect, but when she does so, she is not generally understood to be dishonestly asserting her belief in the correctness of the decision.
} 
candid about those reasons. ${ }^{27}$ But how often are these norms followed in practice? As I have already

said, there is no way to quantify the use substitute arguments, but there are strong reasons to suppose

that the phenomenon occurs frequently enough to merit study.

For example, the media regularly mentions the political affiliation of the President who

appointed various judges ${ }^{28}$ and unselfconsciously refers to the Supreme Court's "liberal" and

"conservative" wings. ${ }^{29}$ These references are relevant only on the assumption that the justices are

influenced by ideological factors unrelated to the arguments from text and precedent that fill their

opinions. ${ }^{30}$ The assumption is apparently shared by the American people, the majority of whom,

27 See, e.g., Micah Schwartzman, Judicial Sincerity, 94 VA.L.REV. 987 (2008); David L. Shapiro, In Defense of Judicial Candor, 100 HARV. L. Rev. 731 (1987). There is a growing body of academic, and a smattering of judicial, dissent. See, e.g., RICHARD A. POSNER, LAW, PRAGMATISM, AND DEMOCRACY 343, 350-52 (2003); Evan H. Caminker, Sincere and Strategic Voting Norms on Multimember Courts, 79 MICH L. REV. 2297, 2312-33, 2347-50 (1999); Scott Idelman, A Prudential Theory of Judicial Candor, 73 TEX. L. REV. 1307 (1995). Cf. Meir Dan-Cohen, Decision Rules, and Conduct Rules: On Acoustic Separation in Criminal Law, 97 HARV. L. REV. 625, 676 (1984) (arguing that "strategic behavior, including bluffing and other forms of deceit" must be expected and that "the option of selective transmission can sometimes be rejected only at the cost of human suffering.") Paul Butler, When Judges Lie (and When They Should), 91 MINN L. REV. 1785 (2007).

28 See, e.g. Jeremy W. Peters, "White House Steps Up Effort to Confirm Federal Judges," NY TIMES, Apr. 26, 2014 ("Presidents Ronald Reagan and George W. Bush left a lasting mark on the federal courts by appointing young, conservative judges who could sit on the bench and affect policy for decades, and Mr. Obama is seeking to do the same with liberal jurists." Cf. Donald Leonhardt, "The Supreme Court Blunder that Liberals Tend to Make," N.Y. Times, June 2, 2014 (noting that liberals have "surrendered seats on the Supreme Court" by not timing retirements with term of Democratic presidents.)

29 See, e.g., Lawrence Hurley, "Supreme Court Blocks Three Oklahoma Executions," REUTERS, Jan. 28, 2015 (referring to division between five conservative and four liberal justices).

30 I do not mean to claim that judges are influenced by narrow, partisan considerations, although, of course, they may be. Instead, my claim has been established if one is convinced that judges are influenced by "high politics" -- by ideological commitments to broad but controversial goals and suppositions about political and economic justice. See Jack, M. Balkin \& Sanford Levinson, Understanding the Constitutional Revolution, 87 VA L. REV. 1045, 1062-63 (2001) (drawing distinction between "high" and "low" politics). Cf. MARK TUSHNET, IN THE BALANCE: LAW AND POLITICS ON THE ROBERTS COURT xiv-xvii (2013) (arguing that justices on the Supreme Court do not "ask themselves what they can do to make the political future of the Republican or Democratic parties rosier," but that they do have "differing constitutional visions ... systematically associated with the two parties.") On some occasions, these goals and suppositions lead to inconsistencies on the case level -inconsistencies that are best explained by the fact that the judge is offering substitute arguments rather than being candid about her underlying motivation. On other occasions, the goals and suppositions might lead a judge to adopt a particular approach to broader structural questions like the appropriate role of, say, text or precedent. The judge may apply this structural approach relatively consistently across cases, but the judge's arguments for the structural approach are still substitutes when the judge does not candidly explain that the structural stance is rooted in the controversial goals and suppositions. But cf. Harry T. Edwards \& Michael A. Livermore, Pitfalls in Empirical Studies that Attempt To Understand the Factors Affecting Appellate Decisionmaking, 58 DUKE L. J. 1895, 1899 (2009) 
according to polling data, think that in at least some cases the Supreme Court is influenced by ideological considerations. ${ }^{31}$

Of course, the media and the public might simply be wrong, but there is a large scholarly literature supporting the "attitudinal model," which claims that the ideological commitments of judges are an important determinant of voting behavior. ${ }^{32}$ If the model is accurate, then judges routinely justify their decisions with legal arguments that substitute for the ideological reasons that actually drive their decisions. True, the model is controversial. At best the literature supporting it demonstrates no more than a correlation between the votes that judges cast and their presumed ideological orientation, often inferred from the political party of the President who appointed them. Critics of the model argue that the correlation is less robust than commonly supposed. Many judicial decisions are unanimous, and the correlation often breaks down, especially in the lower courts and especially with regard to issues that are not politically salient. ${ }^{33}$

Moreover, even if the correlation were perfect, it does not demonstrate causation. A Republican appointed judge may vote consistently on the conservative side of issues, but that may be

(arguing that it is "well understood" that legal reasoning involves moral judgment). For a discussion of the distinction between specific and structural substitution, see $\mathrm{pp} \mathrm{xx}-\mathrm{xx}$, infra.

31 According to a poll conducted by CBS News in 2012, three quarters of all Americans believe that Supreme Court Justices do not decide cases solely based on legal analysis, but rather "sometimes let their personal or political views influence their decisions." See "Polling Report. Com: Supreme Court/Judiciary" available at http://www.pollingreport.com/court.htm. In another poll, conducted by the Public Religion Research Institute in $2013,55 \%$ of those surveyed thought that Supreme Court Justices were influenced by their own political views in making decisions "a lot," and another $32 \%$ thought that they were influenced "a little." Only $8 \%$ thought that the justices were influenced "not at all." Religion \& Political Tracking Poll, PUB. RELIGION RESEARCH INST. (May 23, 2013), available at http://publicreligion.org/site/wp-content/uploads/2013/05/May-Religion-politics-topline1.pdf. 32 For an introduction to the vast literature on the subject, see LEE EPSTEIN, WILLIAM M. LANDES, \& RICHARD POSNER, THE BEHAVIOR OF FEDERAL JUDGES: A THEORETICAL AND EMPIRICAL STUDY OF RATIONAL CHOICE (2013); Eileen Braman, Reasoning on the Threshold: Testing Separability of Preferences in Legal Decision Making, 68 J. POL. 308 (2006); JEFFREY A. SEGAL \& HOWARD J. SPAETH, THE SUPREME COURT AND THE ATTITUDINAL MODEL (1993).

33 See, e.g., Lawrence B. Solum, Book Review: The Positive Foundations of Formalism: False Necessity and American Legal Realism, 127 HARV. L. REV. 2464, 2475 (2014) (arguing that selection effects lead to overstatement of ideological disagreement); Harry T. Edwards \& Michael A. Livermore, Pitfalls of Empirical Studies that Attempt to Understand the Factors Affecting Appellate Decisionmaking, note 30, supra, at 1941 (arguing that studies show few court of appeals cases decided on ideological basis). 
because the Constitution is a deeply conservative document that, faithfully read, yields conservative results. ${ }^{34}$

These criticisms deserve to be taken seriously, but they are not sufficiently weighty to justify jettisoning the attitudinal model. In particular, the fact that "conservative" and "liberal" judges reach the same conclusion in many cases does not demonstrate that their votes are free of ideological influence. The judicial appointment process tends to eliminate ideological outliers. Perhaps liberals and conservatives are both voting their ideologies, but because most judges are only slightly to the left or right of center, the ideologies substantially overlap.

But while unanimity does not demonstrate the absence of ideological decision making, correlation between votes and presumed ideology does tend to demonstrate its presence. True, Republican and Democratic judges can both claim that a seeming ideological bias demonstrates only that the material they are interpreting happens to tilt in that direction. But if both sides make this argument in the same case, they cannot both be right. ${ }^{35}$ We therefore have reasonably strong evidence that at least one side is engaged in substitution.

Another sort of objection to the attitudinal model cannot be so easily dismissed. Critics of the model have complained that correlations between outcomes and ideologies do not show that judges are acting unlawfully. Because constitutional law is often formed by value judgments, judges who act on these value judgments are simply engaged in the practice of constitutional law. ${ }^{36}$ These same value

34 See, e.g., id., at 1927 (arguing that empirical studies are flawed because they do not take into account the role of precedent in judicial decisionmaking).

35 Of course, the material might be sufficiently open-textured to support either view, but if judges do not candidly admit that they are using the freedom the materials provide to support their ideological goals, they are making substitute arguments. I make no claim here about whether substitutions in these instances are hypocritical or unconscious. For a discussion of the distinction, see $\mathrm{pp} x \mathrm{xx}-\mathrm{xx}$, infra.

${ }^{36}$ See, e.g., Harry T. Edwards \& Michael A. Livermore, Pitfalls of Empirical Studies that Attempt to Understand the Factors Affecting Appellate Decisionmaking, note 30, supra, at 1899 (arguing that it is well understood that legal reasoning involves moral judgment). 
judgments contribute to choice of ideology, so no one should be surprised that ideology correlates with judicial outcomes. After all, it is hardly surprising that there is a correlation between people who state that they like chocolate and people who eat chocolate. What it means to like chocolate is that one has a propensity to eat it. So too, on this view, what it means to have an ideological stance with respect to constitutional law is that one will attempt to incorporate a particular set of values into constitutional judgments. The claim that the incorporation is legitimate is especially powerful when the constitutional material is open textured enough to admit to more than one conclusion.

For reasons I outline below, I am happy to embrace this view. In fact, it is at the center of my argument. For present purposes, though, the important point is not whether judicial value judgments are legitimate, lawful, or an inevitable part of constitutional law, but whether judges who are motivated by these value judgments are making substitute arguments. Usually they are, because even when materials are open-textured, judges rarely admit that their interpretation of the materials is determined by a contestable value judgment. Instead, they regularly present themselves and the results they reach as disinterested and ideologically neutral. Because they rarely or never admit that their decisions are motivated by ideology, their actual arguments for their conclusions are substitutes. ${ }^{37}$

In fact, there is something close to a scholarly consensus that, at very least, in close and ideologically freighted constitutional cases in the Supreme Court, the justices are often less than candid about all the reasons that influence their decisions. ${ }^{38}$ Indeed, the justices themselves regularly accuse each other of coming to conclusions that are unjustified by the arguments used to support them. ${ }^{39}$

\footnotetext{
37 See note 32 , supra.

38 See note 29, supra. For a useful compilation of "flip-flops" by Supreme Court justices apparently produced by ideological considerations, see Eric A. Posner \& Cass R. Sunstein, Institutional Flip-Flops (unpublished manuscript on file with author).

$39 \quad$ See, e.g., Romer v. Evans, 517 U.S. 620, 653 (1997) (Scalia, J., dissenting) (“Today's opinion has no foundation in American constitutional law, and barely pretends to"); Payne v. Tennessee, 501 U.S. 808, 844 (1991) (Marshall, J., dissenting) ("Power, not reason, is the new currency of this Court's decisionmaking").
} 
Nor is the problem just about ideology. Appellate courts are multimember bodies, and we do not follow the old English practice of having judges individually state the reasons that motivate their decisions. Even if justices do not horse trade between opinions, it seems obvious that they trade off between present outcomes and future precedent. Justices routinely agree to outcomes on the condition that language is added to the opinion that will influence the outcome in future cases. ${ }^{40}$ The justice who accedes to this bargain endorses an argument that she may not actually support. ${ }^{41}$ And even if none of this goes on, it is simply not plausible that every justice agrees with every statement in every opinion she joins. ${ }^{42}$

\section{Academics}

What about legal academics? If anything, the norm against substitution is even stronger in the academy. Academics claim that their views are entitled to special respect and protection because they are the product of professional expertise and disinterested study. ${ }^{43}$ These claims are at the heart of the

40 A particularly dramatic example occurred during the deliberations over Stovall v. Denno, 388 U.S. 293 (1967). The case established the proposition that suggestive identification procedures might create a due process violation. Initially, Justice Brennan, the author of the opinion, voted to remand the case for a hearing on this claim, but after Justice Clark agreed to vote with him in a companion case establishing a right to counsel at identification procedures, Brennan agreed to change his vote in Stovall and affirm the conviction. These events are described in BERNARD SCHWARTZ, SUPER CHIEF: EARL WARREN AND HIS SUPREME COURT - A JUDICIAL BIOGRAPHY 658-59 (1983).

41

See Evan H. Caminker, Sincere and Strategic Voting Norms on Multimember Courts, note 29, supra. See, e.g., RICHARD A. POSNER, LAW, PRAGMATISM AND DEMOCRACY 343, supra, note 24. See, e.g., Board of Directors' Statement: Academic Freedom and Educational Responsibility, AACU.ORG
(Jan. 6, 2006) https://www.aacu.org/about/statements/academic-freedom (stating that "Academic freedom to explore significant and controversial questions is an essential precondition to fulfill the academy's mission of educating students and advancing knowledge. Academic responsibility requires professors to submit their knowledge and claims to rigorous and public review by peers who are experts in the subject matter under consideration; to ground their arguments in the best available evidence; and to work together to foster the education of students."). See also Council of University of California Faculty Associations Statement on "Civility" and Academic Freedom, WWW. NOODLS.COM (Sept. 11, 2014) http://www.noodls.com/view/7D99855809F08901C88C5113715E8EDCDCDF25FA?7939xxx1410531691 (stating that "Ensuing from academic freedom is the right and duty of faculty to decide, collaboratively and individually, standards and thresholds for teaching and research, without interference from administrators, alumni, or donors. Those determinations are based on standards of scholarly excellence and achievement, which manifest through hiring, academic publishing, and peer review processes in which an individual's academic record is judged by peers."). 
scholarly mission. ${ }^{44}$ Yet, here too, there is cause to doubt that the norms academics espouse in theory are always respected in practice.

The problem is especially acute for the many academics who also represent clients. As lawyers, these advocates have an obligation to advance arguments that support their clients' position whether or not they personally believe them. As academics, they have an obligation to be candid about the positions that they take. Can the two roles be reconciled? Perhaps, but as some of the more reflective academic activists have conceded, the reconciliation is difficult. ${ }^{45}$ No scholar-advocate wants his own scholarship cited back at him when he argues a case. ${ }^{46}$ It is hard to believe that scholars who are

44 For an especially forceful articulation of the point, see J. Peter Byrne, Academic Freedom: A "Special Concern of the First Amendment, 99 YALE L. J. 251, 259 (1989):

The unique point is that academic speech can be more free than the speaker; that the speaker may be driven to conclusions by her respect for methodology and evidence that contradict her own preconceptions and cherished assumptions. The scholar cannot argue merely from her political party, religion, class, race, or gender; she must acknowledge the hard resistance of the subject matter, the inadequacies of friends' arguments, and the force of those of her enemies. That is what scholars mean by disinterested argument - not indifference to outcome, but insistence that commitment not weaken the rigor and honesty by which the argument is pursued.

45 See, e.g., Susan N. Herman, Balancing the Five Hundred Hats: On Being a Legal Educator/Scholar/Activist, 41 Tulsa L. Rev. 637 (2006).

46 See, e.g, oral argument in Ruhrgras v. Marathon Oil, available at : http://www.oyez.org/cases/19901999/1998/1998_98_470:

Justice Ginsburg: And yet there are many authors who have distinguished subject matter jurisdiction as being the most basic from personal jurisdiction, which those authors have ranked along with, say, venue, as a merely dilatory defense, suggesting that there is a hierarchy here, and that subject matter jurisdiction is the more basic.

Mr. Wright: Justice Ginsburg, I would say that I would not agree with them, that I would agree on the great importance of subject matter jurisdiction.

My friends do me the honor of quoting from one of my books in which I in turn quoted ex-Justice Curtis, the questions of jurisdiction are questions of power as between the Central Government and the States. I believe that deeply, but I do not think that personal jurisdiction is some sort of second-class issue. It is an issue that stems from the Constitution, from the Due Process Clause, and I do not think that you can say that Article III takes priority over the Fifth Amendment.

Justice Ginsburg: I was quoting your text when I used the word dilatory. 
litigating a case concerning an issue that they are also writing about do not at least occasionally moderate or change arguments they make in print so as to avoid this embarrassment. ${ }^{47}$

Moreover, even if there is no conscious scholarly substitution, there is bound to be unconscious substitution. ${ }^{48}$ Virtually all lawyers who litigate cases have experienced the phenomenon of coming to agree with the side on which they are arguing. Well-known psychological processes push toward this sort of unconscious substitution. ${ }^{49}$ Is it really plausible that scholars are immune from this distortion or that the distortion is somehow confined to the briefs they write and never works its way into the scholarship they produce?

As Richard Fallon has pointed out in his powerful but careful critique of the practice, law professors who sign amicus briefs rarely read and fully consider all the citations and arguments in these advocacy documents. ${ }^{50}$ Indeed, the main defense of the practice is that readers understand that the professors do not stand behind the arguments in the same way that they stand behind arguments made in scholarly work. That observation, if true, provides a partial defense against the criticism that professors are unfairly trading on their reputation for objectivity. It does so, however, only by conceding that they are making substitute arguments and that readers understand this fact. Since the professors do not vouch for, and are not understood to vouch for, all the arguments being made, it must be that these arguments serve as substitutes for the actual reasons that motivate their association with the brief.

\section{Mr. Wright: I imagined that I recognized the words.}

[Laughter]

47 It is probably for this and related reasons that a few legal publications, like The Supreme Court Review, decline to publish articles about cases written by advocates in those cases. My impression is that this admirable practice is not widely followed by other journals.

$48 \quad$ For discussion of unconscious substitution, see $\mathrm{pp} \mathrm{xx}-\mathrm{xx}$, infra.

$49 \quad$ See note $\mathrm{xx}$, infra.

50 See Richard H. Fallon, Scholars' Briefs and the Vocation of a Law Professor, 4 J. LEGAL ANALYSIS 223, 25558 (2012) 
What about law professors who do not engage in litigation? The problem is less obvious here, but it is nonetheless real. Consider the empirical research conducted by John O. McGinnis, Matthew A. Schwartz, and Benjamin Tisdell on law professors at the top twenty-one law schools as defined by the U.S. News \& World Report 2002 survey. ${ }^{51}$ The authors matched professors signing public letters about issues of public concern with political ideologies as reflected by campaign contributions. The letters purported to reflect objective expertise and not ideology, but, perhaps not surprisingly, there was a strong correlation between political ideology and the positions advanced in the letters.

More troubling still is the evidence that substitute arguments infect scholarly articles which do not purport to be advocacy documents. Adam Chilton and Eric Posner examined recent law review articles by ten randomly selected professors from each of the top fourteen American law schools as ranked by U.S. News and World Report. ${ }^{52}$ Recent law review articles written by the professors were coded as "liberal," "conservative," or "neutral" using a checklist of political indicators widely employed by social scientists to measure judicial behavior. Like McGinnis, Schwartz, and Tisdall, Chilton and Posner used campaign contributions as an indicator of the political ideology of the professors. As so measured, their results demonstrated a clear correlation between political ideology and the political valence of the articles that the professors produced. The correlation was especially pronounced with respect to scholars writing about constitutional law.

The Chilton-Posner study does not prove conclusively that scholars are widely resorting to substitute argument. As the authors themselves acknowledge, the results are consistent with "selection" rather than substantive bias. Professors may select topics to write about where their ideological predispositions line up with authentic arguments drawn from the materials. Moreover, like

51 See John O. McGinnis, Matthew A. Schwartz \& Benjamin Tisdell, The Patterns and Implications of Political Contributions by Elite Law School Faculty, 93 GEO. L. J. 1167, 1190-99 (2005).

52 See Adam S. Chilton \& Eric A. Posner, An Empirical Study of Political Bias in Legal Scholarship (unpublished manuscript on file with author). 
advocates of the attitudinal model, Chilton and Posner must deal with the daunting problem of detecting substitution without taking a position on whether the materials themselves actually support liberal or conservative positions. ${ }^{53}$

Nonetheless, the data Chilton and Posner have collected are suggestive, and they are reinforced by the very strong sense, shared by almost everyone in the academy, that there are identifiably "liberal" and "conservative" constitutional scholars and that these scholars tend to produce identifiably "liberal" and "conservative" work. Once again, if one thinks that constitutional analysis cannot or should not be divorced from ideology, these outcomes will come as no surprise. Still, to the extent that scholars claim to be "objective" and that their conclusions transcend ideology, the studies tend to demonstrate that they are making substitute arguments. Of course, scholars are more ready than lawyers to be nuanced in their conclusions and to candidly discuss their presuppositions, but when for example, they examine historical materials or the meaning of text, liberals and conservatives alike often manage, whether consciously or unconsciously to make things come out "the right way." Put differently, their arguments about things like history and text are at least sometimes substitutes for the real concerns that motivate their work.

\section{Politicians}

This problem is still more acute with respect to public debate by political figures who do not purport to be constitutional experts. Politicians who opine about, say, the constitutionality of the Affordable Care Act or of campaign finance regulation are not, and usually do not claim to be steeped in the materials necessary to make an informed constitutional judgment based on the constitutional

$53 \quad$ The Chilton-Posner data tends to show a stronger correlation between imputed political beliefs and academic work among liberal scholars than among conservative scholars. This data might be interpreted as suggesting that the materials themselves favor liberals. On the other hand, it is also consistent with the proposition that conservatives are more honest or that law schools select for conservatives who are more open to liberal views. 
methodologies that they, themselves embrace. Occasionally, a public figure will admit as much and concede that he is relying on the judgment of experts. More frequently, though, politicians advance constitutional argument as their own. When they do so, argument from text and original understanding serves as a rhetorical placeholder for arguments that are grounded in contemporary political or moral judgments.

It is not surprising, then, that politicians are often caught in contradictions. For example, as Eric Posner and Cass Sunstein have pointed out, in recent years, Democrats and Republicans have switched sides on the constitutionality of the filibuster, the extent of the President's recess appointment power, and the constitutional propriety of presidential signing statements depending on who was in control of which institution. ${ }^{54}$ Once again, the very ubiquity of the practice serves as a partial defense for it. Because the political use of constitutional argument is so common and so transparent, few are actually fooled. But why then is the practice so common?

\section{A Typology of Substitute Arguments}

Before we can answer this and related questions, we need to make some distinctions between various types of substitute arguments. Substitutes can be classified based upon the mental state of the individual making them and the level at which they are made. With regard to mental state, substitute arguments can be nonmotivating, hypocritical, or unconscious. ${ }^{55}$ With regard to level, they can be specific, structural, or foundational. These variables, in turn, produce a matrix with nine possible cells.

See Eric A. Posner \& Cass R. Sunstein, Institutional Flip Flops (unpublished manuscript on file with author). 55 I do not mean to claim that these categories are static or uncomplicated. Actors can, and often do, shift from one mental state to another. Depending on circumstances, they substitute between substitutes. One could further complicate the analysis by observing that internal confusion and conflict sometimes make it impossible to provide a clear and complete account of one's thoughts. People "may, and commonly do, cling to incompatible propositions at the same time." STUART HAMPSHIRE, "Sincerity and Single-Mindedness," in FREEEDOM OF MIND AND OTHER ESSAYS 240 (1971). Their minds might also be changed by "self-watching," and, if such change occurs, one would have to decide which state of mind is "authentic." See id, at 246. On the distinction between conceiving of sincerity as single-mindedness and conceiving it as a correspondence between belief and utterance, See Micah Schwartzman, note 26, supra, at 994. For the sake of clear exposition, my discussion above abstracts from these various difficulties. 
Before mixing and matching, however, we need to define some terms and reach some preliminary normative conclusions.

\section{A. Mental State}

1. Nonmotivating substitutes. A substitute argument is nonmotivating-or merely nonmotivating - when its proponent believes that it is sound or that it might be sound but would not be motivated to make the argument but for reasons that are unrelated to the argument. Suppose for example that I favor a state's restrictions on abortion because I think that all abortions should be banned as an unjustified taking of human life. Instead of making this argument, I claim that this particular restriction should be banned because it does not "unduly burden" the abortion right within the meaning of the Supreme Court cases that establish this standard as the test for permissible regulation. ${ }^{56}$ I make the undue burden argument in good faith, believing it to be correct, but would not make it but for my belief that all abortions are illegitimate.

Notice that as I use the term here, nonmotivating substitutes are not only sincerely believed but may be also be causally linked to a conclusion. A person who is not motivated to make the "undue burden" argument might nonetheless think that the argument provides sufficient cause for banning the abortion practice in question. There are, after all, many arguments that we have no internal reason to make even though we believe them to be true. ${ }^{57}$ Nonmotivating substitutes arise when our internal reason for making the argument does not derive from the argument itself.

It follows that when one makes two, cumulative arguments, they need not be substitutes for each other. Even if neither argument is a necessary or sufficient cause for the conclusion, both arguments can be authentic. What makes a substitute nonmotivating is the absence of a sufficient

$56 \quad$ See Planned Parenthood of Southeastern Pennsylvania v. Casey, 505 U.S. 833, 878 (1992); Gonzales v. Carhart, 530 U.S. 124, 144 (2007).

57 On the distinction between internal and external reasons, see note $\mathrm{x}$, supra. 
internal cause for making the argument, not the absence of either a sufficient or necessary cause for reaching the conclusion that the argument supports.

At least at first, arguments like this seem unproblematic. Even if the proponent of the argument is not motivated by it, the argument's target might be. The proponent is not misleading the target or unfairly manipulating him. Since she, herself, believes that the nonmotivating argument is sound, there is no tension between making the argument and respecting the integrity of the argument's target.

Indeed, in a diverse society, there is much to celebrate about nonmotivating substitutes. They reflect a search for common ground - a way in which people can come to agreement on some things even if they disagree about others. And even if there is no agreement, nonmotivating substitutes can still build empathy and connection. Forcing oneself to explain or justify a position within another's framework can help the proponent of a nonmotivating substitute to understand why another person might think in the way that she does. ${ }^{58}$

For these reasons, advocates of nonmotivating substitutes should not always be condemned; sometimes they should be praised. But although nonmotivating arguments are the least troublesome variant of substitutes, they can still pose problems. I do not mean to suggest that the problems are necessarily intrinsic features of all nonmotivating arguments. They suggest reasons why we should sometimes be wary of such arguments, but they do not provide ground for criticizing them in all situations.

58 John Rawls calls this sort of argument "reason by conjecture," JOHN RAWLS, POLITICAL LIBERALISM 462 (2005), which he defines as "argu[ing] from what we believe, or conjecture, are other people's basic doctrines, religious or secular, and try[ing] to show them that, despite what they might think, they can still endorse a reasonable political conception that can provide a basis for public reasons." Id. at 465-66. Rawls approves of this type of argument provided that "[w]e . . openly explain our intentions and state that we do not assert the premises from which we argue, but that we proceed as we do to clear up what we take to be a misunderstanding on others' part, and perhaps equally on ours." Rawls might be taken, then, to endorse reason by conjecture so long as the reason is merely nonmotivating and not hypocritical. See also note xx, supra. 
What are the reasons for caution? Suppose the proponent happens to believe in the argument, but would make it hypocritically even if she did not believe in it. If so, and if making hypocritical arguments (discussed below) is morally blameworthy, then, it would seem, the proponent should not escape censure because of the happenstance that she finds the argument convincing.

This problem is made worse by the difficulty in reliably distinguishing between nonmotivating and hypocritical substitutes. It will often be difficult for the proponent of a supposedly nonmotivating substitute to know whether she really would favor the argument in a hypothetical situation where it did not support a position she holds for other reasons. Moreover, even if the argument really is merely nonmotivating, targets of the argument might suspect that it is hypocritical or unconscious. To the extent that hypocritical and unconscious arguments have a demoralizing effect that undercuts authentic deliberation (discussed below) ${ }^{59}$, this suspicion will be demoralizing as well.

Moreover, even if an argument really is merely nonmotivating, there remains something troubling about foraging about for reasons that one might not otherwise develop or rely upon. Imagine, for example, that an advocate opposes a federal statute that requires the government to pay prevailing wages to the construction workers it employs. ${ }^{60}$ Her reason for opposition is that she dislikes labor unions, and the statute assists unions in organizing workers. She knows that this reason is not going to persuade a judge to invalidate the law, so she undertakes a massive effort to come up with an argument that will work. Eventually, she hits pay dirt: It turns out that years ago, the Congress that enacted the statute did so in order to eliminate competition from lower paid, African American workers. $^{61}$

\footnotetext{
$59 \quad$ See ppxx-xx, infra.

60 See Davis-Bacon Act, Pub. L. 71-98, 46 Stat. 1494 (1931).

61 See ARMAND J. THIEBOLT, PREVAILING WAGE LEGISLATION : THE DAVIS-BACON ACT, STATE "LITTLE

DAVIS-BACON" ACTS, THE WALSH-HEALEY ACT, AND THE SERVICE CONTRACT ACT 30 (1986) ("The federal statute was enacted in 1931 in large part as a means by which to protect the higher wages of white construction workers
} 
Should we be worried when the advocate attacks the law on this ground? One might think that if the ground she comes up with is valid and if she herself believes it to be valid, there can be no cause for concern. But even if the reason she advances for invalidating the statute is sound, we might still be concerned about the reason for developing the reason. Something like this concern lies behind the constitutional prohibition on discriminatory arrests and prosecutions. If a law enforcement officer motivated by hatred of African Americans sets out to find a good reason to arrest an African American motorist, his discovery of such a reason does not shield him from constitutional censure, at least if he would never have searched for the reason in the first place but for the race of the motorist. ${ }^{62}$

Similarly, suppose a "liberal" Supreme Court justice must decide whether to rule in favor of a "liberal" position in a case. Imagine that the justice would not so rule unless there is a good argument for doing so. But imagine as well that when the initial arguments offered by the parties fail to meet this threshold, the justice asks his clerks to investigate additional arguments (perhaps obscure, procedural issues) supporting the liberal side. Imagine, finally, that the justice would not look for such arguments in cases where the arguments vindicated a "conservative" position. Even if the clerks manage to come up with a valid argument, many would conclude that the justice has done something wrong by engaging in this discriminatory searching.

in northern cities such as New York, Philadelphia and Detroit from being diluted through 'cheap colored labor' from the southern states."). Cf. Brazier Const. Co. v. Chao, 2002 U.S. Dist. LEXIS 28523, 8-9 (D.D.C. 2002) (rejecting argument that Davis-Bacon Act should be invalidated because legislative history shows that it was originally acted to prevent blacks from competing for jobs).

62 See, e.g., Whren v. United States, 517 U.S. 806, 813 (1996) ("We of course agree ... that the Constitution prohibits selective enforcement of the law based on considerations such as race."). Cf. Oyler v. Boles, 368 U.S. 448,456 (1962) (decision to prosecute may not be constitutionally based on "an unjustifiable standard such as race, religion, or other arbitrary classification). Perhaps what is doing the work in this hypothetical is the immorality of racial hatred, not the search for a substitute argument. But most people would have the same intuition about an officer who searches for a reason to arrest a motorist with, say, an anti-gun control bumper sticker on her car. The intuition remains the same even though in our society opposition to gun control, unlike racial hatred, is morally permissible. 
Some of us have a similar intuition if, for example, opponents of a Supreme Court nominee scour the nominee's record to come up with a reason that would otherwise never have come to light, but that discredits the nominee. It is not coincidence that many people find "opposition research" somewhat unsavory and that political candidates try to distance themselves and their campaigns from it.

One fear that lies behind these concerns is that outcomes will be distorted by the unequal energy and resources that may be used to uncover nonmotivating substitutes. When placed under a microscope, the world is an ugly place. None of us is a saint; all of our actions and all the actions of our government are tainted. Nonmotivating substitutes are always available if only we look hard enough for them. We might have just reason to fear that people in power will look harder for some things than others.

The target of a substitute argument might also be concerned about what the argument portends for the future. Consider the abortion hypothetical again. Perhaps the "undue burden" test is a compromise that people favoring a broad abortion right are willing to live with because it ends an otherwise exhausting and divisive conflict. This settlement entails a willingness to examine individual abortion restrictions to determine whether they in fact pose undue burdens, and the believer in abortion rights is willing to abide by its terms in good faith. But now suppose that such a believer discovers that abortion opponents are unwilling to live with the compromise. True, the opponents are making an argument within the bounds of the compromise in this case, but they will move further just as soon as circumstances permit. Faced with this prospect, an abortion rights advocate might think twice about unilaterally adhering to the compromise. ${ }^{63}$

\footnotetext{
63 The argument here is subtly different from a standard "slippery slope" concern. See e.g., Frederick Schauer, Slippery Slopes, 99 HARV. L. REV. 361 (1985). The problem is not, or not just, that a concession on one
} 
Justice Scalia has pointed to precisely this concern in the context of gay marriage. When the Court's majority defended certain rights of gay men and lesbians in ways that purport to stop short of protection for gay marriage, Scalia has warned darkly that we should "not believe it." 64 Of course, Scalia himself opposes the Court's decisions on their own terms. The warning therefore seems to be directed to others who might be inclined to accept these decisions so long as they are not a way station on route to protection for gay marriage. ${ }^{65}$ His point seems to be that people who might otherwise accept limited protections should instead reject them because proponents are not willing to live with this compromise. Now that Justice Scalia's prophesy has come to pass, one might imagine that some people who supported the more limited protections as a defensible compromise feel misled and manipulated. ${ }^{66}$

Nonmotivating arguments harm not just their targets but also their proponents. These arguments have the unfortunate effect of holding an advocate hostage to a position that may not be relevant to her actual claim and distracting attention from that claim. Consider, for example, recent controversies about putatively excessive force directed against African American men in cases like the killing of Michael Brown in Ferguson, Missouri; Trayvon Martin in Sanford, Florida; Eric Garner in New York City; and Freddie Gray in Baltimore, Maryland.

Much of the public debate has centered on claims that, on the facts of these individual cases, the killings were unjustified. But these are often nonmotivating arguments. Those making the arguments no doubt believe that the killings were unjustified, but many of these advocates are

point will inevitably lead to bigger concessions in the future. It is rather that the initial concession would not be made in the first place in the absence of an agreement that both sides will be satisfied with the compromise.

$64 \quad$ Lawrence v. Texas, 539 U.S. 558, 604 (2005) (Scalia, J., dissenting). See also United States v. Windsor, 133 S. Ct. 2675, 2709 (2014) (Scalia, J., dissenting).

65 It follows that the warning is, itself, a nonmotivating substitute.

66 I do not mean to claim that the the Court's earlier arguments were necessarily nonmotivating. On one reading, the Court's majority did not offered a compromise at all, but simply decided the cases before it without committing one way or the other to future decisions. One might also imagine that limited arguments were motivating at the time they were made but that, later and on reflection, the justices concluded that they could not be limited. For a discussion of the difficulty in making binding commitments to limited arguments, see pp xx, infra. 
motivated not (just) by the perceived injustice in these particular cases but by the desire to correct the problem of pervasive racism in the criminal justice system.

As a logical matter, there is no necessary connection between these two positions. It might be true that Brown, Martin, Garner, and Gray were unjustly killed but that there is no broader problem, or that Brown, Martin, Garner, and Gray were justly killed but that there is a broader problem. As a practical matter, though, there is a tendency for the two arguments to run together. If it turns out that on the particular facts of the cases, the killings were justified, the failure of the substitute argument tends to impeach the motivating claim that in general African American men are treated unjustly. Moreover, because advocates of the substitute argument know that this will happen, they will be tempted to continue to defend their position in the individual cases even if it turns out that the facts are against them. And when they do this, their opponents can discredit them as tendentious ideologues. Of course, the same dynamic works in reverse when advocates on the other side claim that the individual killings were justified to advance their position that the criminal justice system as a whole is not racist.

2. Hypocritical substitutes. A substitute argument is hypocritical when it is, or might be, persuasive to its target but does not persuade the person who advances it. ${ }^{67}$ Suppose, for example, that an advocate favors legalization of marijuana and attacks the federal statute prohibiting marijuana use on the ground that marijuana use is local activity beyond the reach of Congress's commerce clause powers. ${ }^{68}$ The advocate does not actually believe this argument and would reject it in, say, the context

67 Arguments that accept arguendo another's framework are not hypocritical substitutes even if the advocate does not himself believe that the framework is correct so long as the proponent genuinely believes that the framework dictates the ultimate conclusion. A person who says "as a Christian, you should oppose abortion" is not engaged in hypocritical substitution even if the person is not a Christian so long as the person genuinely believes that abortion is inconsistent with Christianity. In contrast, a non-Christian who falsely claims to believe that Christianity is inconsistent with abortion would be acting hypocritically, as would a non-Christian who says, "you should be a Christian, and, therefore, you should oppose abortion." See note 46, supra.

68 Cf. Gonzales v. Raich, 545 U.S. 1 (2005) (finding that the Controlled Substances Act does not violate the Commerce Clause and that California's Compassionate Use Act is invalid to the extent that it conflicts with federal law). 
of federal regulation of domestic violence. ${ }^{69}$ She nonetheless advances it instrumentally in order to achieve her true goal -- marijuana legalization - which she supports for reasons unrelated to the commerce clause. ${ }^{70}$

Hypocritical substitutes are more troubling than substitutes that are merely nonmotivating. They raise questions about candor that are not present when an advocate authentically believes what he says. When we discover that someone has engaged in hypocritical argumentation, we feel betrayed by the messenger, even when we remain convinced by the message. Consider, for example, how much difference it makes to our opinion of Lyndon Johnson if we believe on the one hand that he was authentically converted to the cause of civil rights or on the other that he made a cynical calculation about the need to break with his regional, racist supporters if he was to gain national power. ${ }^{71}$

Still, we need some account of why it matters in a public setting whether or not the argument is internal to the advocate. Even if the advocate has no reason to believe that something is true, why should this matter if there is reason for the target to believe in its truth? ${ }^{72}$ Put differently, even if hypocritical argument changes our opinion of the messenger, why should it change our opinion of the message ${ }^{73}$ Imagine alternative scenarios where in one case, a hypocritical advocate persuades me that an argument is correct and in the other where I come up with the same conclusion on my own. It seems irrational to treat the same argument differently just because of its source. Moreover, the irrationality

$69 \quad$ Cf. United States v. Morrison, 529 U.S. 598 (2000) (finding that the Violence against Women Act, 42 U.S.C. $\S 13981$, exceeded Congress' powers under the commerce clause and the fourteenth amendment.) Of course, it might be possible to distinguish the two situations, and a belief in the distinction might be honestly held. The hypothetical example assumes that the advocate sees no distinction.

$70 \quad$ The distinction between nonmotivating arguments and hypocritical arguments roughly parallels the distinction that Micah Schwartzman draws between judicial candor and sincerity. See Micah Schwartzman, Judicial Sincerity, note $\mathrm{x}$, supra, at 995.

71 For a discussion, see ROBERT A. CARO, THE YEARS OF LYNDON JOHNSON: THE PASSAGE OF POWER 8-10 (2012).

72 On the distinction between internal and external reasons, see $\mathrm{pp} x \mathrm{x}$, supra.

73 See MARTIN P. GOLDING, LEGAL REASONING 8 (1984) (suggesting that judge's sincerity is irrelevant to justifiability of a decision). 
of treating the message differently might cause me to soften my initial disapproval of the messenger.

Whatever his motives, we can be grateful to Lyndon Johnson for his crucial support for civil rights.

There are nonetheless reasons for concern about both the message and the messenger when arguments are advanced hypocritically. When I discover that an advocate does not believe his own argument even though it seems right to me, I am led to wonder what the advocate knows that I do not know. The advocate must see a flaw in the argument that is not apparent to me, and it is only natural to suppose that he is not disclosing the flaw because he wants me to reach a conclusion for reasons that have nothing to do with the argument that he is actually advancing. Even if I cannot immediately figure out what the flaw is, it makes sense to be more skeptical of the argument than I would be if I had come up with it myself or if I knew the advocate was advancing it in good faith. ${ }^{74}$ In other words, hypocritical arguments give rise to a reasonable fear that their target is being tricked rather than persuaded.

For this reason, hypocritical arguments have the capacity to undermine the trust and shared purpose that is essential to authentic dialogue. If reasons for action really amounted to no more than disembodied logic, free floating in the universe until they somehow come into consciousness, then this sense of a joint enterprise would be less important. But this is not the way that the real practice of discussion, reason-giving, and persuasion works.

From a certain point of view, the argument that Martin Luther King offered in his Letter from a Birmingham Jail would have been just as eloquent and persuasive if they were formed by random winds blowing across the sands on a beach. But in fact it matters deeply that the letter was written by an embodied human being -- Martin Luther King -- whom we know something about and who wrote it while he was in a Birmingham jail. When we affiliate ourselves with his argument, we are not - or at

$74 \quad$ This phenomenon provides at least a partial explanation for why advocates never admit that they are making substitute arguments. See $\mathrm{pp} \mathrm{xx}$, supra. Cf. Micah Schwartzman, Judicial Sincerity, note $\mathrm{x}$, supra, at 101415 (arguing that "[j]udges are more likely to give sufficient reasons when they believe that the reasons they give are sufficient.") 
least not just - accepting abstract logical propositions. We are also choosing to ally ourselves with him and with his lived struggle. So too, and more generally, when we change our minds after a dialogue with someone else, the change often reflects something more than acceding to the power of deracinated logic. We are also choosing to build bonds of fellowship and affection. ${ }^{75}$

For reasons that I have already discussed, it might be thought that these observations challenge rule-of-law ideals, which rest on the impersonality of legal reasons. One might worry that the law cannot be fair and equal if the force of legal argument depends not just on the argument itself but on the identity of the person making it. On this view, even if our actual practice of argument and persuasion is ad hominem, we should strive to make it less so and to evaluate legal claims on their merits. It might even follow that it is the effort to root out hypocritical substitute arguments rather than the arguments themselves that are destructive of civic community.

There is no doubt something to the argument that tolerating hypocritical substitutes is the price we pay for an impersonal rule of law. I address this point in more detail below. For now, though, the important point is that the condemnation of hypocritical arguments might also be seen as providing a necessary condition for the flourishing of impersonal argumentation. Perhaps we have a general duty to each other to evaluate reasons for action without being prejudiced by our opinion of the people advancing the reasons. Creating a community capable of realizing this ideal, though, requires at least a

75 It is for just this reason that classical studies of rhetoric emphasized the importance of what Aristotle called "ethos," which he defined as creating the impression of the advocate's character and credibility. See ARISTOTLE, THE RHETORIC OF ARISTOTLE 91 (Lane Cooper trans., 1932). But cf. ARISTOTLE, THE NICOMACHEAN ETHICS 1096a (ROGER CRISP, ED. AND TRANS. 2000) (“For one might love both, but it is nevertheless a sacred duty to prefer the truth to one's friends.") Cicero warned that it is "impossible for the listener to feel indignation, hatred or ill-will, to be terrified of anything, or reduced to tears of compassion, unless all those emotions, which the advocate would inspire in the arbitrator, are visibly stamped or rather branded on the advocate himself." MARCUS TULLIUS CICERO, DE ORATORE 333 (E.W. Sutton trans., 1942). Similarly, Quintilian claimed that “It is ... . pre-eminently desirable that [the advocate] should be believed to have undertaken the case ... [from a] moral consideration." QUINTILIAN, 2 INSTITUTIO ORATORIA 9 (H.E. Butler trans., 1954). For a discussion of modern use of these techniques, see Michael Frost, Ethos, Pathos, \& Legal Audience, 99 DICK.L. REV. 85, 85 (1994) (arguing that lawyers "often ignore the importance of two especially effective nonrational means of persuading judges and juries to accept their arguments: emotional appeals based on the facts of the case or the decisionmakers' personality and their own personal appeal or credibility.") 
minimal level of trust. Before we can insist on impersonal justice, we need some sense that we are all participating in a common enterprise with agreed rules of engagement. It might be thought that the rules necessarily include a requirement of candor and respect for the integrity of our interlocutors. The prevalence of hypocritical argument leaves us always wondering what our interlocutors are up to and whether they are playing straight with us. Ironically, then, hypocritical argumentation actually draws our attention to the individual making the argument and so, is also in tension with rule-of-law values.

When hypocritical arguments are made by a judge, they undermine the rule of law in a second way. On the classical, liberal model of adjudication, we expect judges to provide reasons for their decisions that extend beyond the facts of the decisions themselves. They therefore bind themselves to apply the same reasons in future cases to the extent that the cases really are the same. ${ }^{76}$ For generations, critics of this liberal model have advanced reasons to be skeptical about how much these norms really bind judges. ${ }^{77}$ At least, though, if the reasons advanced in the first case are the real reasons, the human taste for consistency will push judges toward applying the same reasons in a second case. ${ }^{78}$ If the reasons are a conscious fraud, advanced solely to achieve a result actually supported by other, unstated reasons, then the consistency norm loses some of its force.

Finally, hypocritical substitutes risk failing on their own terms and, when they do, they can lead to disputes about issues far removed from what actually matters to the disputants. Consider, in this connection the romance between constitutional progressives and the equal protection clause. The source of the attraction is no mystery. The American constitutional tradition strongly favors negative

76 See, e.g., Wechsler, supra note $\mathrm{x}$, at 19, 33; ALEXANDER M. BICKEL, THE LEAST DANGEROUS BRANCH: THE SUPREME COURT AT THE BAR OF POLITICS 204-05 (1986). See generally, G. Edward White, The Evolution of Reasoned Elaboration: Jurisprudential Criticism and Social Change, 59 VA. L. REV. 279 (1973).

77 See, e.g., Jerome Frank, Book Review, 40 YALE L. J. 1120(1931); Mark V. Tushnet, Following the Rules Laid Down: A Critique of Interpretivism and Neutral Principles, 96 HARV. L. REV. 781 (1983).

78 But cf. pp xx, infra. 
rights. ${ }^{79}$ It equates liberty with the absence of government interference and coercion with government intervention. For progressives, who seek a constitutional grounding for their demands for government activism, this tradition poses a substantial obstacle. ${ }^{80}$

Equality arguments provide a way to surmount this obstacle. Even though the Constitution does not guarantee positive rights, if these rights are granted to one class of people, equality arguments can force the government to grant them to others as well. The Supreme Court's opinion in DeShaney v. Winnebago County Department of Social Services ${ }^{81}$ provides an example. Writing for the Court, Justice Rehnquist rejected petitioner's argument that there was an affirmative constitutional right to protection from private violence. Even as he rejected this claim, however, Justice Rehnquist wrote a singlesentence footnote that provided a roadmap for how a similar claim, grounded in equality, might succeed: "The State may not, of course, selectively deny its protective services to certain disfavored minorities without violating the Equal Protection Clause." ${ }^{82}$

The problem for progressives is that this equal protection claim, unlike the substantive due process claim actually advanced in DeShaney, yields only a comparative right. Equality claims can therefore be met by either ratcheting up or ratcheting down government services. In theory, the state could satisfy an equality argument for government protection by denying protection to everyone. When

79 See, e.g., DeShaney v. Winnebago County Dep't of Social Services, 489 U.S. 189, 195 (1989) (due process clause does not "impose an affirmative obligation on the State"); Obergefell v. Hodges, S.Ct. (2015) (Thomas, J., dissenting) ("In the American legal tradition, liberty has long been understood as individual freedom from governmental action, not as a right to a particular governmental entitlement."); Jackson v. City of Joliet, 715 F. 2d 1200, 1203 ( $7^{\text {th }}$ Cir. 1983) (Posner, J.) (The Constitution "is a charter of negative rather than positive liberties").

80 See, e.g., Robin West, Constitutional Scepticismn, 72 B.U.L.REV. 765, 776 (1992) (arguing that the "Constitution appears to be fundamentally at odds with progressive ideals and visions" because without positive rights it "leaves untouched the very conditions of subordination, oppression, and coercion that relegate some to lesser lives of drudgery, fear, and stultifying self-hatred.")

81489 U.S. 189 (1989).

82 Id. at 197 n.3. 
progressives make equality arguments, they are therefore betting on the fact that, faced with a choice, the state will ratchet up rather than ratchet down.

Often the bet will pay off. The fact that it is a bet, though, demonstrates that equality arguments are sometimes hypocritical substitutes. If progressives were really wedded to the equality position, they would be satisfied with either alternative. But that is rarely the case. It is hard to imagine that many progressives would be happy in the admittedly unlikely event that a jurisdiction responded to an equality argument on facts like those presented in DeShaney by abandoning police protection for everyone. Similarly, how many progressives who say they oppose the death penalty because it is imposed on a racially discriminatory basis think that the world would be a better place if equality were achieved by executing more white people ${ }^{83}$ Would advocates of income equality prefer a world in which everyone was equally impoverished? Of course, there may be some such people, but at least the progressives who use equality as a political tactic to achieve their substantive ends are making hypocritical substitute arguments.

What are the costs of hypocritical substitutes in this context? Sometimes the arguments will fail on their own terms. They can misfire in two ways. First, the government might call the progressives' bluff and ratchet down services. In Palmer v. Thompson, ${ }^{84}$ a jurisdiction faced with an order to desegregate its swimming pools, closed them instead. The Supreme Court held that withdrawal of services for blacks and whites alike satisfied the equal protection clause. ${ }^{85}$ The upshot was no swimming pools for anyone. Some people may think this is an improvement, but others will think it is the worst of all worlds.

83 Cf. Randall Kennedy, McClesky v. Kemp: Race, Capital Punishment, and the Supreme Court 101 HARV. L. REV. 1388, 1392-93 (arguing that "[t]here has been relatively little discussion" of increasing the execution rate when the victim is African American because "many of the advocates for racial justice are also death penalty abolitionists.")

$84 \quad 403$ U.S. 217 (1971).

85 But cf. Griffin v. County School Board of Prince Edward County, 217 U.S. 218 (1964) (holding that closing of all local public schools to avoid integration violated the equal protection clause). 
The second and more likely possibility is that the state will defeat the equality claim by pointing to a supposedly relevant difference between the class granted and denied the benefit. For example progressives tried to use an equality argument to secure government funding for poor women seeking abortions. They pointed to the inequality between women whose pregnancy ended in live births, who were entitled to Medicaid funding, and women whose pregnancy ended in abortions, who were not. The claim failed, in part because the Supreme Court thought that there was a relevant distinction between abortions and live births. ${ }^{86}$ Similarly, when progressives attempted to use an equality argument to secure more funding for poor school districts, the Court found that the funding differential was rationally related to a legitimate state interest. ${ }^{87}$

These cases illustrate the fact that hypocritical arguments of this sort do not always work. Worse yet, though, when they fail, they divert discussion from what really matters to questions that are deeply - even ludicrously - irrelevant. Consider, for example, the argument, most prominently adopted by Justice Ruth Ginsburg, that the abortion restrictions should be conceptualized as a denial of gender equality. ${ }^{88}$ In a famous article, ${ }^{89}$ Judith Jarvis Thomson attempted to flesh out this argument by imagining a series of bizarre hypotheticals where men were put in a position analogous to that of pregnant women. Would we really tolerate a situation, she asked, where a man found himself hooked up against his will to a violinist with kidney disease for nine months until a transplant could be arranged ${ }^{90}$ Of course, the two situations are not exactly analogous, so, to meet objections to the analogy, Thomson had to invent even more bizarre hypothetical worlds where, for example, pregnancy was caused by free floating people seeds that might pass through protective screening over windows. ${ }^{91}$

$86 \quad$ See Maher v. Roe, 432 U.S.464 (1977); Harris v. McRae, 448 U.S. 297 (1980).

$87 \quad$ See San Antonio Ind. School Dist. v. Rodriguez, 411 U.S. 1 (1973).

88 Ruth Bader Ginsburg, Essay: Some Thoughts on Autonomy and Equality in Relation to Roe v. Wade, 63 N.C. L. REV. 375 (1985).

89 Judith Jarvis Thomson, A Defense of Abortion, 1 PHIL. \& PUB. AFFS. 47 (1971).

$90 \quad$ Id., at 48-49.

$91 \quad$ Id., at 59 
These hypotheticals, in turn, generated a large literature defending and attacking the analogy. ${ }^{92}$ Are pregnant women and fetuses really like men hooked up to violinists or are they more like conjoined twins ${ }^{93}$ or a doctor and patient dying of incurable throat cancer ${ }^{94}$, or a father and son where the father's sperm was stolen by an unscrupulous physician and inseminated into a woman ${ }^{95}$ Surely, our response to the abortion controversy should not turn on trying to answer questions like this. ${ }^{96}$ Yet trying to provide such answers is often the consequence of substituting arguments that we don't care about for arguments that we do.

3. Unconscious substitutes. The third variant of substitute argument does not involve deliberate misleading of one's interlocutor. When an advocate makes an unconscious substitute argument, she believes in good faith that the argument is not hypocritical. In fact, though, through wellknown mechanisms such as cultural cognition and confirmation bias, she persuades herself of an argument that she would not believe but for the instrumental purpose that it serves. ${ }^{97}$

There is strong reason to think that unconscious substitutes are very common. As already noted, most litigators have had the experience of convincing themselves that their arguments are sound. More broadly, a wealth of social science data demonstrates that people regularly come to believe what it is useful for them to believe, that these beliefs are firmly held, and that they are often

92 See James E Mahon, Innocent Burdens, 71 WASH. 7 LEE L REV. 1429, 1429 (2014) (noting that Thomson's article "is the most reprinted article on abortion ever written").

93 See Kenneth E. Himma, Thompson's Violinist and Conjoined Twins, 8 CAMB.Q. HEALTHCARE ETHICS 429 (1999) (arguing that conjoined twins is a more apt analogy).

$94 \quad$ James E. Mahon, Innocent Burdens, note 89, supra, at 1435.

95 Francis J. Beckwith, Personal Bodily Rights, Abortion, and Unplugging the Violinist, 32 Intern. Phil. Quart. 105, 115 (1992).

96 Cf. Richard Posner, The Problematics of Moral and Legal Theory, 111 HARV. L. REV. 1637, 1675 (1998) (arguing that the violin analogy is unhelpful "because the case is outside our empirical experience; it belongs to science fiction.")

97 This category overlaps with what David Pozen has called "Sartrean Bad Faith." See David E. Pozen, Constitutional Bad Faith (unpublished manuscript on file with author). Cf. JEAN-PAUL SARTRE, BEING AND NOTHINGNESS 89 (1992). On the distinction between Sartre's conception of bad faith and Freudian repression, see id. at 90-96 
resistant to change even in the face of overwhelming evidence on the other side. Some research demonstrates that judges, too, are subject to this sort of bias. ${ }^{98}$

Unconscious substitutes are especially insidious because proponents have no sense that they are doing anything wrong. Moreover, unconscious substitutes harm not just the target of the argument, but the proponent as well. Unconscious substitutes allow people to slide off hard choices, but they avoid psychic tension only by obstructing the advocate's ability to achieve his own goals.

Suppose, for example, that I oppose the use of genetically modified foods and have managed to convince myself that the scientists who claim that the foods are safe to eat are biased-something that I would not believe but for my general opposition to genetic modification. There are actually two risks here. First, my opinion about the general question might change if I squarely and honestly confronted the scientific evidence. It is, after all, the threat to this belief that motivates the unconscious substitute in the first place. The unconscious substitute therefore not only commits me to an argument that I do not "truly" believe; it also shields me from revision of a position that I might "truly" wish to abandon. ${ }^{99}$

Second, it may prove difficult for me to confine my substitute argument to the purpose for which it is advanced. Suppose that someone makes a similar claim to scientific bias regarding the safety of vaccines, which I believe should be required. Now I will either have to take this claim more seriously

98 See, e.g., Chris Guthrie et al, Blinking on the Bench: How Judges Decide Cases, 93 Cornell L. Rev. 1, $22-25$ (2007); Dan M, Kahan, "Ideologing In" or "Cultural Cognition Of" Judging: What Difference Does it Make?, 92 Marq. L. Rev. 413, 419-20 (2009); Paul M. Secuda, Cultural Cognition Insights into Judicial Decisionmaking in Employee Benefit Cases, 3 labor \& Emp. L. Forum 1, 8 (2013); Eric Berger, The Rhetoric of Constitutional Absolutism, 56 Wm. \& Mary L. Rev xxx, xxx (2015); Dan Kahan, Foreword: Neutral Principles, Motivated Cognition, and Some Problems for Constitutional Law, 125 HARV. L. REV. 1 (2011),

99 My use of quotation marks are meant to signal a complication that I cannot fully explore here. The problem I identify is rooted in the assumption that personal identity is linked to a rationalistic and conscious choice of goals not distorted by unconscious, nonrational urges. It also assumes a model under which there is a sharp distinction between a person's motivations and actions and where motivation precedes action rather than action forming motivation. A person holding a different conception of personal identity or of human agency might reach different conclusions. 
than it deserves to be taken in order to be consistent with my skepticism in the genetic modification case or engage in still more elaborate rationalization in order to explain to myself and others why the bias charge makes sense in one context but not in the other.

Despite these evils, the effort to root out unconscious substitutes is sometimes more harmful than the arguments themselves. Consider the impact of Freud's famous claim that Adler's and Jung's disagreements with him were rooted in neurosis ${ }^{100}$ or Stalin's similarly famous claim that opposition to his regime was based on false consciousness. ${ }^{101}$ Charges like these can be destructive of the very possibility of good faith discussion. A claim of unconscious motivation substitutes ad hominem attack for reasoned refutation.

Perhaps more seriously, such a claim assumes that the person making the accusation uniquely stands outside the unconscious motivations that infect the judgment of everyone else. How do we know that Freud, himself, was not unconsciously motivated when he accused Adler and Jung of unconscious motivation? If thoroughgoing psychological determinists are right, all argument - indeed all conduct - is caused by unconscious forces. Even Freud himself did not go this far, but one need not to see how these attacks can get out of hand. The target of the attack is unlikely to take it sitting down. She will respond with her own claims of unconscious substitution and both sides will then be left bickering over mental states instead of grappling with substantive disagreement.

It does not follow that the effort to root out unconscious substitutes is always misguided or that it is always bound to fail. Some of the most penetrating social theory of the last two hundred years has been designed to reveal underlying social structures that are unconscious. Indeed, my own

100 See PETER GAY, FREUD: A LIFE FOR OUR TIME 223, 235-36 (1988) (noting Freud's view that “Adler was suffering from paranoid delusions of persecution" and that Jung was "all out of his wits . . behaving quite crazy.") 101 See Robert V. Daniels, The Left Opposition as an Alternative to Stalinism, 50 SLAVIC REV. 277, 283 (1991) (noting that "the Stalin-Bukharin leadership" promoted the idea that "[p]olitical differences were the expression of class differences and, since the party and its general line by definition represented the proletariat, any deviation was automatically antiproletarian, probourgeois, and, hence, inadmissible"). 
ambition for this article is to explore the unconscious or half-conscious roots of a widespread social practice. It does follow, though, that making the charge of unconscious motivation always imposes a cost and that the cost is especially high when it is directed at an individual and when it is, itself, a substitute for taking seriously and considering on the merits the arguments made by that individual.

This cost, in turn, makes the problem of unconscious substitutes still more serious. There can be no doubt that these substitutes exist and pose an obstacle to authentic, liberal dialogue Still, for the reasons I have just outlined, the obvious remedy - trying to bring unconscious substitutes into consciousness - is often ineffective and can also make liberal discourse difficult or impossible.

\section{B. Level}

Substitute arguments can also be advanced at different levels.

1. Specific arguments. Virtually all the examples I have discussed so far have been at a high level of specificity. By "specificity" I mean that the argument has salience in only a relatively small number of situations. Of course, specificity is a matter of degree rather than kind. Some substitute arguments are so specific that it is hard to imagine they will apply in any other situation. When this is so, we can say that they have no "spill-over effects" on other cases. Perhaps the most famous effort to make an argument so specific as to have no such effects was in Bush v. Gore, where the majority wrote that its "consideration is limited to the present circumstances, for the problem of equal protection in election processes generally presents many complexities." ${ }^{102}$

Other arguments have somewhat larger, but still quite limited, spill-over effects. For example, arguments based on balancing numerous factors substantially limit but do not entirely eliminate spillover. Because every case is different, the balance struck in one case commits one to relatively little 
about how the next case will be resolved. ${ }^{103}$ Conversely, when a court announces an abstract rule that purports to cover a multitude of situations and is relatively impervious to differences between cases, spill-over effects are relatively larger. ${ }^{104}$

Spill-over effects are a special problem for advocates of substitute arguments. Of course, even if one is not making such an argument, spill-over can be a problem. Suppose a judge truly believes that, say, a presumptive rule favoring warrants strikes the right balance between privacy and law enforcement. In reaching this judgment, the judge will have to take into account the fact that the general rule will produce the "wrong" outcome in some cases. All rules commit us to some spill-over costs in exchange for the predictability and administrative advantages of relatively rigid structures.

When arguments are honestly made, though, these spill-over effects are built into the original calculation that justifies the rule. The proponent of the rule believes that on balance, the cost of the spill-over effects are justified by the benefits of the rule. In contrast, in the case of hypocritical arguments, the proponent's true belief is that the rule itself is unjustified. Invocation of the rule is hypocritical in the sense that it is designed only to achieve the "right" result in the immediate case to be decided. The proponent does not believe that the spill-over effects are justified by the good the rule does, and will therefore try to avoid following it in future cases.

Of course, proponents of hypocritical arguments know that they may not succeed in ignoring the rule in the future, so, one might suppose, they will try to avoid substitutes that take the form of a

103 See T. Alexander Aleinikoff, Constitutional Law in the Age of Balancing, 96 YALE L. J. 943, 979 (1987) (arguing that balancing either "demands a new balance in every case" or is "often undermined by new interests or different weights for previously considered interests").

104 But cf. Kathleen M. Sullivan, Foreword: The Justices of Rules and Standards, 106 HARV. L. REV. 22, 63 (1992) (observing that even if "rules promote economies for the legal decisionmaker by minimizing the elaborate, time-consuming, and repetitive application of background principles to facts" such economies "will be offset if decisionmakers spend time inventing end-runs around them because they just cannot stand their over-and underinclusiveness") 
rigid rule and favor substitutes that involve balancing or rest on narrow circumstances unlikely to arise again.

There are nonetheless forces that pull in the opposite direction. First, an outcome with no spillover effects can signal that it is the result of a substitute argument. For example, critics of the majority opinion in Bush v. Gore were quick to seize on the language quoted above as proof that the majority was utilizing a hypocritical substitute. ${ }^{105}$ More broadly, defenders of rules regularly make the point that balancing, multifactored, and ad hoc tests are "unprincipled" in the sense that they allow advocates to reach desired outcomes without paying the price of consistency. ${ }^{106}$ An advocate wishing to persuade others with a hypocritical argument therefore has an incentive to at least create the appearance that the argument is broad rather than specific. In this fashion, an argument that starts out being hypocritical might morph into one that is genuine in the sense that the advocate comes to believe that consistent application of the rule will shield him from the charge that he is a hypocrite.

Second, it may be quite easy to shield one from this charge without actually creating the undesired spill-over. The problem here is that no rule can completely control the future. Part of the difficulty is a product of the malleability of legal language and the existence in a mature legal system of a vast network of intersecting and conflicting rules to choose from. In a later case, the proponent of a rule may be able to exploit ambiguities in the rule or counter it with another rule so as to avoid spill-over effects. Moreover, the announcement in case one that one will follow a rule in the future provides no guarantee that this commitment will be honored in case two. Case one might be overruled, and, even if

105 See, e.g., Frank I. Michelman, Suspicion, or the New Prince, 68 U. CHI. L. REV. 679,685 \& n. 15 (2001) (noting that the Bush majority's "newly minted" doctrine was "perceived as problematic from birth by the very majority that authored it").

${ }^{106}$ See, e.g., Antonin Scalia, The Rule of Law as a Law of Rules, 56 U. CHI. L. REV. 1175, 1182 (1989) (arguing that when judges balance all the factors "equality of treatment is difficult to demonstrate and, in a multi-tiered judicial system, impossible to achieve; predictability is destroyed; judicial arbitrariness is facilitated; judicial courage is impaired.") 
it is not, the rule might be refined in case two with exceptions or qualifications. Indeed, this sort of refinement over time is at the heart of the common law process. ${ }^{107}$

2. Structural arguments. Whether relatively broad or narrow, specific arguments provide reasons why a particular result should be reached. In contrast, structural arguments are arguments about arguments. They provide reasons why specific arguments should or should not count as reasons. Suppose, for example, the issue is whether the President can make recess appointments during brief, inter-session congressional recesses. ${ }^{108}$ A proponent of such appointments might make the specific argument that they are constitutionally permissible because such appointments have been made throughout our history. ${ }^{109}$ An opponent of this position might engage on this specific level (e.g., "no they haven't been"), ${ }^{110}$ but, alternatively, she might counter the specific argument with a structural challenge: Why should history be the determinant of constitutionality? ${ }^{111}$ The challenge, in turn, forces the proponent into a structural response - e.g., respect for fixed and settled practices encourages stability and gives proper respect to the considered judgment of many generations.

At first, one might suppose that structural arguments are a solution to the problem of substitution. At the metalevel, where many different controversies are potentially at stake and where the structures are likely to be in place for some time to come, the spill-over effects can be huge. When people formulate general structures, they often act behind a veil of ignorance. Since it will be difficult or

107 See Mark V. Tushnet, Following the Rules Laid Down: A Critique of Interpretivism and Neutral Principles, 96 HARV. L. REV. 781, 808-814 (1983),

108 See N.L.R.B. v. Noel Canning, 134 S. Ct. 2550 (2014).

109 See id., at 2559-60 (arguing that "Presidents have made recess appointments since the beginning of the Republic").

110 See id. at 2600 (Scalia, J., concurring in the judgment) (arguing that history does not support majority's conclusion).

111 See id., at 2592 (Scalia, J., concurring in the judgment) (complaining that the majority "sweeps away key textual limitations on the recess-appointment power" and "justifies those atextual results on an adverse possession theory of executive authority.") 
impossible to predict what future specific disputes the structures will apply to, one might as well advance honest arguments for why one structure is generally better than another. ${ }^{112}$

It turns out, though, that substitution is actually a very serious problem for structural argumentation. The problem might be less serious if we could establish a final victory for one structure or another. But that is not the way that American constitutional law works. As things presently stand, decision makers have available a variety of different and incompatible structures for decision making. They can resort to constitutional text, to original understanding of the text, to tradition and practice, to prior decisions, to conceptions of the good, and so forth. ${ }^{113}$ Despite what some scholars claim, ${ }^{114}$ there seems to be no generally accepted rank ordering of these structures. Moreover, few judges seem to believe that their resort to a structure in one case binds them to use the same structure in the next case. On the contrary, many Supreme Court justices pride themselves in being "pragmatic" and having no fixed, worked out theory of judging. ${ }^{115}$

This state of affairs provides an open invitation for substitute argument. A judge who favors a broad recess appointment power can point to practice and tradition and argue in favor of this structure not because of an honest belief that it is the right one, but because it provides a justification of the specific result he wants to reach in the case before him. Moreover, he can do this with minimum spillover costs because our open textured and unsystematic constitutional practice allows him to turn

112 See, e.g., John O. McGinnis \& Michael B. Rappaport, Originalism and the Good Constitution, 98 GEO. L. J. $1693,1738-40$ (2010) (arguing that "the dynamic nature of constitutional law" means that people and government do not know what a provision will mean in the future).

113 See, generally, PHILLIP C. BOBBITT, CONSTITUITONAL FATE: THEORY OF THE CONSTITUTION (1982) (identifying six "modalities" of constitutional interpretation: historical, textual, doctrinal, prudential, structural, and ethical).

114 See Richard H. Fallon, Jr., A Constructivist Coherence Theory of Constitutional Interpretation, 100 HARV. L. REV. 1189, 1252-68 (1987) (defending hierarchical rank ordering of methods, but only in unusual circumstances where methods do not lead to same result).

115 See, e.g., STEPHEN BREYER, ACTIVE LIBERTY: INTERPRETING OUR DEMOCRATIC CONSTITUTION 7-8 (2005) (disclaiming any "theory of constitutiohnal interpretation" and explaining that "most judges agree that ... language, history, tradition, precedent, purpose, and consequence are useful" but disagree "just where and how to use them.") 
around and argue for some version of textualism or for a theory of the good, or for respect for prior case precedent to resolve the next case.

The problem with structural argumentation runs even deeper. There is a sense in which any argument in favor of any structure must be a substitute. Suppose, for example, that a justice wants to argue that strict gun control laws are unconstitutional because they violate the original public meaning of the second amendment's text. ${ }^{116}$ When this structure is challenged - why should we be governed by the original public meaning? - what kind of structural argument can be offered in response?

Broadly speaking, there are three possibilities. The advocate can say "we should respect the Constitution's original public meaning because the Constitution, interpreted according to its original public meaning, tells us to." Chief Justice Marshall made an argument analogous to this in Marbury v. Madison, where he argued that the intent of the Constitution's framers to make it binding made it binding. ${ }^{117}$ But, despite its pedigree, this argument is obviously circular. No structural argument can bootstrap itself into acceptance, no matter how vociferously it asserts its own validity.

Since any argument internal to the putative structure is circular, advocates are tempted by a second sort of argument that goes outside the structure to justify it. For simplicity, suppose that there are only two possible alternatives: resolution based on original public meaning or resolution based on the contemporary view of judges. An advocate of the original public meaning approach might then say that this technique is better than resort to contemporary decisions by judges because, say, original

116 See District of Columbia v. Heller, 128 S. Ct. 2783 (2008).

117 Marbury v. Madison, 1 Cranch. 137, 175 (1803) ("Certainly all those who have framed written constitutions contemplate them as forming the fundamental and paramount law of the nation, and consequently the theory of every such government must be, that an act of the legislature, repugnant to the constitution, is void.") 
public meaning respects decisions made by "We the People," ${ }^{118}$ or because it constrains the power of judges, ${ }^{119}$ or because it gives force to decisions made under conditions that assure wisdom. ${ }^{120}$

But whereas arguments internal to the structure are circular, external arguments are self-

refuting. Indeed, they are self-refuting precisely because they are not circular. None of the reasons I have suggested for utilizing original public meaning is, itself, dictated by original public meaning. That is why the arguments are not circular. But that is also why embrace of any of these arguments contradicts the position that judges should base their decisions solely on original public meaning.

Suppose, for example, that an opponent of original public meaning claims that the Constitution was not, in fact, agreed to by We the People (many people were excluded from the ratification process), or that it does not effectively constrain judges (original meaning is sufficiently ambiguous that judges can resort to it to do whatever they want), or that it was not made under conditions that promoted a wise result (the Constitution's framers could not possibly understand modern conditions). How are these objections to be evaluated? The circularity problem means that the conflict between them and the arguments for originalism cannot be resolved by the original public meaning itself. But remember that we have hypothesized that the alternative to original public meaning is decision making by judges. If the argument is to be adjudicated by contemporary judges, then, according to advocates of original public meaning, the decision will not be made by We the People or in a fashion that constrains the power of judges, or under conditions that guarantee wisdom. The argument for originalism therefore turns out to be self-refuting.

118 See, e.g., Kurt T. Lash, Originalism, Popular Sovereignty, and Reverse Stare Decisis, 93 VA. L. Rev.1437, 1442 (2007) ("Popular sovereignty holds that laws created by ordinary political majorities are less legitimate than the supermajoritarian law of the Constitution due to their more attenuated relationship to the actual will of the people").

119 See, e.g., Antonin Scalia, Originalism: the Lesser Evil, 57 U.CIN.L.REV. 849, 864 (1989) (arguing that originalism does not aggravate the principal weakness of judicial review "for it establishes a historical criterion that is conceptually quite separate from the preferences of the judge himself").

120 See, e.g., McGinnis \& Rappaport, Originalism and the Good Constitution, supra note xx, at 1734 ("The beneficience of the good constitution derives from the consensus support it gained among the enactors"). 
The failure of these arguments leaves us with a third possibility: We should favor the original public meaning approach because the approach leads to the invalidation of strict gun control laws. But this is a substitute argument; the structural arguments for original public meaning are substituting for the specific arguments in favor of a broad right to own firearms. Put differently, if an advocate with this motivation were persuaded that the original public meaning approach did not support broad gun rights, she would abandon the approach.

To be clear, this is not merely a problem for originalism. The same difficulty haunts all structural constitutional arguments, whether for an "intended application" approach, a broader "original understanding" approach or a "living constitution," approach. All such arguments must be substitutes if they are to avoid both circularity and self-refutation. It is therefore not surprising that advocates of a wide variety of approaches regularly justify them on the ground that they produce what the advocate thinks of as good outcomes. ${ }^{121}$ The problem is that if the advocate thinks the outcomes are good, she must have some reason (not grounded in the approach itself) for thinking this, and the structural argument is merely a substitute for this reason.

Sometimes advocates for particular structural approaches try to avoid this problem by focusing on a broad range of results rather than a single, controversial area of doctrine. They try to build broader coalitions for their approach by claiming that, over a range of cases, the approach produces more good outcomes than bad, or more good outcomes than any likely alternative.

This strategy, if successful, does indeed produce broader coalitions, but it does not escape the problem of substitution. An advocate using the strategy claims that the favored approach produces

121 See, e.g., Michael W. McConnell, Originalism and the Desegregation Decisions, 81 VA. L. REV. 947 (1995) (defending originalism because it is consistent with Brown v. Board of Education); David A. Strauss, Why Conservatives Shouldn't Be Originalists, 31 HARV J. L. \& PUB. POL. 1 (2008) (arguing that precedent based system produces better results than originalism); MARK V. TUSHNET, TAKING THE CONSTITUTION AWAY FROM THE COURTS 129-33 (arguing that constitutional enforcement through ordinary political process will produce better results than judicial review). 
good outcomes $a, b, c \ldots$ and that these outcomes outnumber or outweigh bad outcomes $1,2,3 \ldots$ If a potential ally believes that outcome $\mathrm{c}$ is bad, but outcome 3 is good, she may, for overlapping but not identical reasons, agree to the structure. Increasing the number of possible outcomes produced by the structure increases the chances of a coalition supporting it.

It remains true, though, that members of the coalition are supporting it with substitute arguments. Why, after all, does the advocate believe that, say, a, b, and c are good outcomes, while 1 , 2 , and 3 are bad? It cannot be just because these are the outcomes produced by the favored structure, for this is again to argue in a circle. It must be, then, that there are independent reasons for these judgments and that the structural arguments are substituting for these reasons.

3. Foundational arguments. The discussion of structural argumentation has focused on reasons why one might adopt one or another constitutional structure. Unfortunately, however, there is nothing about constitutional structure that makes it unique. The problem reemerges at every level, until, on at least one, nightmarish view, we are left with nothing but substitute arguments all the way to the bottom.

Suppose, for example, an advocate claims to support the original public meaning approach on the ground that it maximizes freedom. A skeptic might then ask why it is a good to maximize freedom. Perhaps the proponent replies that freedom is necessary to human flourishing, which leaves the skeptic asking why this is a good, and so on. The skeptic, like an annoying four year old, can keep asking the "why" question at every level, and the advocate, like an exhausted parent, must ultimately reply "because I said so." But then all the steps leading to the bottom are substitutes for this ultimate reply. ${ }^{122}$

122 Over thirty years ago, Arthur Leff put the point as well as anyone. At the conclusion of his article, Unspeakable Ethics, Unnatural Law, 1979 DUKE L. J. 1229, 1249, he wrote: 
There are two solutions commonly offered to this problem. The first solves it by limiting the audience for the argument. Perhaps there is a sufficiently broad "overlapping consensus" in the Rawlsian sense concerning the rightness of one of the intermediate steps that allows us not to go all the way to the bottom. ${ }^{123}$ For example, maybe enough people, for whatever reason, or, indeed, for no reason, believe that human freedom is a good, so that the advocate can safely ignore the people who disagree. The advocate can then assume agreement on this point and try to persuade others in this limited but nonetheless very large audience that the original public meaning approach supports human freedom.

I will have more to say about overlapping consensus later, but, for now, it is important to see that such a consensus does not change the substitute nature of the argument. The right question to ask regarding substitute arguments is not whether others share the proponent's view, but why the proponent herself has come to it. If the proponent favors original meaning only because this approach promotes freedom, but believes in freedom only because it is necessary for human flourishing, then we are headed down the long chain that leads to "because I said so" at the bottom. The fact that others find no need to follow the proponent to the bottom - or, rather, reach the bottom by a different path -does not change the fact that the proponent herself has made a substitute argument.

As things now stand, everything is up for grabs.

Nevertheless:

Napalming babies is bad.

Starving the poor is wicked

Buying and selling each other is depraved

Those who stood up and died resisting Hitler, Stalin, Amin, and Pol Pot - and General Custer too - have earned salvation

Those who acquiesced deserve to be damned.

There is in the world such a thing as evil.

[All together now:] Sez who?

God help us.

123 Cf. JOHN RAWLS, POLITICAL LIBERALISM 158-68 (2005) (discussing how constitutional consensus might come about among people with different comprehensive doctrines). 
A second solution plays off the artificiality of this highly academic form of reasoning. Perhaps a few philosophers decide what they think by wrestling with the implications of foundational ideas, although it is hard to believe that even many of them live their ordinary lives this way. Be that as it may, this is not an accurate account of how most people think about things that matter to them. They have some indeterminate mix of intuition, inherited ideas, prejudices, unconscious urges, practical reasons, unquestioned assumptions, and comfortable modes of thought that lead them to conclusions.

This point is undoubtedly correct, but it merely restates rather than resolves the substitute argument problem. Suppose a Supreme Court justice is assigned to write the majority opinion in a case that upholds the Affordable Care Act. We could (barely) imagine a justice writing that he thought the act was constitutional because of his intuitions, inherited ideas, prejudices, unconscious urges, practical reasons, unquestioned assumptions, and comfortable modes of thought. But no justice writes opinions that look anything like this. In fact, no one having even a casual conversation about the Affordable Care Act says anything like this. If the real basis for our decisions is this messy and unsystematic mix of halfconscious, sometimes disreputable, and usually ill-formed reasons, it follows that virtually all the public arguments we make are substitutes.

\section{The Problem of Function}

What purposes do substitute arguments serve? This section explores two separate but interrelated questions: What incentives do individual constitutional advocates have to make substitute arguments; and what, if any, social purpose do they serve?

\section{A. Why Do People Make Substitute Arguments?}

If, as I have argued above, structural and foundational arguments are inevitably substitutes, ${ }^{124}$ and if specific arguments are rooted in substitute structural and foundational arguments, the answer to 
the question posed by the title to this subsection is straightforward: People make substitute arguments because, ultimately, there are no other arguments. Instead, at the bottom of the chain of justification, there is only an assertion of power. Everything else amounts to a substitute. If this disturbing proposition is correct, we have solved the problem of substitutes, but only by acknowledging a much more serious problem at the core of reason-giving and dialogue.

I will return to this problem in the next subsection, where I provide an external account of substitution. First, though, it is worth exploring the internal motivations of constitutional actors. These actors are more than willing to bracket the larger problem, if, indeed, it has ever occurred to them. They regularly make arguments on the specific or structural levels that ignore the twin difficulties of circularity and self-refutation and assume consensus well short of the bottom. What are we to make of argumentative substitution at the specific and structural levels where it does not seem to be a conceptual requirement built into the problem of foundations?

The most obvious reason to advance a substitute argument is that the real argument is likely to be unavailing. When an advocate consciously or unconsciously thinks that her candid articulation of her real concerns will not achieve the desired outcome, she is bound to look around for substitutes.

Sometimes, there will be a specific obstacle to achieving the desired outcome, and a substitute will overcome this obstacle. For example, binding Supreme Court precedent might doom an argument against the Affordable Care Act based on substantive due process, but an opening might remain to argue that the Act violates the commerce clause. On other occasions, substitutes might hide disreputable arguments that, perhaps, the advocate is unwilling to admit even to herself. Arguments about the threat of inflation or budget deficits might substitute for racially-tinged objections to redistributive legislation. In still other cases, substitute arguments help to assemble a coalition that would not otherwise form. An argument that large scale incarceration is immoral might not attract 
majority support, but if combined with an assertion that hyper-incarceration is too expensive or ineffective, it might prevail.

It should come as no surprise, then, that substitute arguments are often attractive. But there is a puzzle here. For reasons that I have discussed above, there is also good reason to be suspicious of substitute arguments and that suspicion, in turn, makes them less effective. Of course, an advocate might believe that she is able to hide the fact of substitution, but the widespread understanding that substitutes are very prevalent makes deception much more difficult.

In some circumstances, the suspicion of substitution is so powerful that the arguments are not just condemned but actually outlawed. Consider, for example, Hunter v. Underwood, ${ }^{125}$ where the Supreme Court invalidated a provision of the Alabama Constitution that disfranchised all persons convicted of misdemeanors of moral turpitude. Although one could easily imagine constitutionally legitimate arguments for this provision, the Court invalidated it because, long ago when the measure was enacted, these arguments were substitutes for motivating arguments premised on racist ideology. Hunter is part of a long line of cases holding that substitute arguments cannot be utilized to shield otherwise unlawful discrimination based on a suspect classification.

Although the Court remains sharply divided on the issue, at least some precedent supports the extension of this principle to other areas of equal protection jurisprudence. ${ }^{126}$ Indeed, on one prominent theory, the elaborate system of tiered scrutiny that defines standard equal protection analysis is all about substitutes. Heightened scrutiny of certain classifications is designed to "smoke out"

$125 \quad 471$ U.S. 222 (1985).

126 For example, with respect to rational relationship review, compare United States Railroad Retirement Bd. v. Fritz, 449 U.S. 166, 179 (1980) ('Where, as here, there are plausible reasons for Congress' action, our inquiry is at an end. It is, of course, 'constitutionally irrelevant whether this reasoning in fact underlay the legislative decision,' . . . because this Court has never insisted that a legislative body articulate its reasons for enacting a statute" (quoting Flemming v. Nestor, 363 U.S. 603, 612 (1963)) with id. at 187 (Brennan, J., dissenting) (“[E]qual protection scrutiny under the rational-basis test requires the courts first to deduce the independent objectives of the statute, usually from statements of purpose and other evidence in the statute and legislative history, and second to analyze whether the challenged classification rationally furthers achievement of those objectives") 
the use of substitute argument where, it is thought, the argument is especially likely. ${ }^{127}$ Similarly, the Court's suspicion of content based regulation of speech in the first amendment context is designed to differentiate between regulation authentically designed to serve nonspeech-related interests and the use of these purported interests to make arguments that substitute for speech-related reasons. ${ }^{128}$ Some of the Supreme Court's early decisions striking down abortion regulations that purported to be based on health and autonomy rationales were probably grounded in the suspicion that these reasons were substitutes for opposition to the abortion right. ${ }^{129}$

Yet even as the law outlaws substitutions, it also encourages them. Consider, for example, the problem of race discrimination. Although the law formally bans official action based on substitutes for racial reasons, the Court has made it exceedingly difficult to prove that a substitution has occurred. ${ }^{130}$ These onerous requirements, in turn, leave the ban significantly underenforced. The underenforcement suggests that, whatever the formal doctrine says, the Court is prepared to tolerate a fair amount of substitution. ${ }^{131}$

Strikingly, in the context of affirmative action, some justices have gone beyond tolerating substitution; on one reading of their opinions, they would actually require it. According to current

127 See, e.g., Johnson v. California, 543 U.S. 499, 506 (2005) (justifying strict scrutiny of racial classifications as a means to "smoke out" illegitimate uses of race). Cf. JOHN HART ELY, DEMOCRACY AND DISTRUST 146 (1980) (explaining strict scrutiny as a means of discovering improper motivation).

128 See David A Strauss, Persuasion, Autonomy, and Freedom of Expression, 91 COLUM. L. REV 334, 338 (1991) ("The many other first amendment doctrines that have developed are, arguably, designed to guard against the danger that the government is only pretending to be concerned about noise, litter, offensiveness, or hostile audience reaction but in fact is reacting to the feared persuasiveness of the speech that it seeks to suppress"). 129 See, e.g., City of Akron v. Akron Center for Reproductive Health, Inc., 462 U.S. 416 (1983) (invalidating legal requirement that second trimester abortions be performed in hospitals); Planned Parenthood of Central Missouri v. Danforth, 428 U.S. 52 (1976) (invalidating legal requirement for written consent of spouse); Thornberg v. American College of Obstetricians \& Gynecologists, 476 U.S. 747 (1986) (invalidating statute requiring the use of abortion technique that provided the most protection for life of the fetus in postviability abortions).

130 See, e.g., McCleskey v. Kemp, 481 U.S. 279 (1987) (rejecting relevance of empirical data purporting to show racial discrimination in application of the death penalty); United States v. Armstrong, 517 U.S. 456 (1996) (refusing to provide defendant with discovery so that he could make out a racially discriminatory prosecution claim); Arlington Heights v. Metropolitan Housing Development Corp. 429 U.S. 252, 264-68 (1977) (rejecting disproportionate impact as a method of proving illicit intent).

131 See, e.g., Brannon P. Denning \& Michael B. Kent, Jr., Anti-Anti-Evasion in Constitutional Law, 41 FLA. ST. L. REV. 397 (2014). 
doctrine, statutes and government policies that facially discriminate in favor of racial minorities are subject to the same strict scrutiny as statutes and policies that disadvantage them. ${ }^{132}$ This doctrine means that many affirmative action programs are unconstitutional when frankly justified on remedial or diversity grounds. But even as it has invalidated these programs, some of the justices have indicated that they are willing to accept substitute arguments that achieve the same end.

Thus, the justices have suggested that the heightened scrutiny used in cases like Hunter is inappropriate in cases where government action designed to achieve affirmative action goals is facially neutral. A facial admissions preference for racial minorities in state-run universities or the direct use of race to achieve balance in public schools is subject to strict scrutiny, but intentionally achieving the same diversity ends by admitting the top ten percent of each high school class to the state university or deliberately gerrymandering the boundaries of school districts is constitutionally unproblematic. ${ }^{133}$ If the government intends a policy to benefit historically disadvantaged minorities, substitution is not just permissible; it is mandatory. ${ }^{134}$

132 See, e.g., Adarand Constructors v. Pena, 515 U.S. 200, 223-24 (1995); Gratz v. Bollinger, 539 U.S. 244, 270 (2003).

133 See Fisher v. University of Texas at Austin, 133 S. Ct. 2411 (2013) (noting that the program at issue was one that reintroduced race-based considerations, not the "top ten percent" statute); with id., at 2433 (Ginsburg, J. dissenting) ("only an ostrich could regard the supposedly neutral alternatives as race unconscious"); Parents Involved in Community Schools v. Seattle School Dist. No. 1, 551 U.S. 701, 789 (2007 (Kennedy, J. concurring in part and concurring in the judgment) ("School boards may pursue the goal of bringing together students of diverse backgrounds and races through other means, including strategic site selection of new schools; drawing attendance zones with general recognition of the demographics of neighborhoods; allocating resources for special programs; recruiting students and faculty in a targeted fashion; and tracking enrollments, performance, and other statistics by race. These mechanisms are race conscious but do not lead to different treatment based on a classification that tells each student he or she is to be defined by race, so it is unlikely any of them would demand strict scrutiny to be found permissible").

134 One might reformulate these arguments to make them seem authentic rather than substitute. Perhaps the justices advancing this position believe that diversity is a legitimate government interest, but that it is unconstitutional if pursued in a fashion that disadvantages particular, identifiable individuals based upon their race. A ten-percent plan or racially gerrymandered school districts, like an affirmative action plan that counts race along with multiple other factors in admitting students, might then be authentically defended as satisfying this test.

However, there are two difficulties with this explanation. First the test itself seems to embrace a kind of substitute. True, under all of these approaches, no particular student can be certain that her race caused her to be disadvantaged, but it is certain that race caused an anonymous group of students to be disadvantaged. Plans of this nature seem to pass constitutional muster because there is the possibility of argumentative substitution with 
It seems then, that in different contexts, constitutional doctrine outlaws, permits, and requires substitution. Moreover, on a broader canvass, it is obvious that whatever the formal doctrine says, substitute arguments are all around us. Indeed, as outlined above, there is every reason to believe that the justices themselves regularly make them, even as they also regularly condemn them. ${ }^{135}$ In short, we are living in a world where everyone is ashamed to admit doing what everyone knows everyone is doing. Why this elaborate charade?

Part of the explanation relates to the training and culture of legal professionals. As discussed above, lawyers practicing within the adversary system are expected as a matter of professional ethics to make substitute arguments. Even in this context, lawyers occasionally exhibit doubt and embarrassment about substitution, but the necessity for these arguments is built into the ideology of advocacy. ${ }^{136}$ Of course, judges and legal academics are not advocates for clients. They are, however, trained as lawyers. The habits of advocacy, developed over the course of legal education and a professional career, can easily slop over into a domain where they are less appropriate. On some level, judges and academics know that their different role requires abandonment of these habits. They are ashamed to remain in their grip. Still, it is no easy matter to escape them.

But although professional training and acculturation are part of the problem, they are not all of it. To understand the deeper sources of the difficulty, we need to go beyond an internal account of

regard to any individual. Because the criteria are fluid and vague, the failure of any particular student to secure admission can be attributable to substitute, nonracial factors.

Second, as a doctrinal matter, the justices' embrace of a ten-percent plans and gerrymandering of school districts is analytically different from multi-factored affirmative action in admissions. In the latter case, the Court has subjected the plans to strict scrutiny precisely because some students are disadvantaged because of race. But when a jurisdiction does not facially pursue affirmative action but, instead, hides behind a facially neutral procedure, it seems that no more than rational basis is required. See id. This difference in the level of scrutiny depends on the government offering a substitute explanation for the ten-percent plan or the gerrymandering of school boundaries.

135 See pp xx, supra.

136 See $\mathrm{pp} \mathrm{xx}$, supra. 
individual motivation and explore what an external observer might identify as the social objectives achieved by substitution.

\section{B. The Social Function of Substitute Arguments}

We can begin to understand the social function of substitute arguments by comparing them to John Rawls' conception of overlapping consensus and public reason ${ }^{137}$ and Cass Sunstein's closely related idea of an undertheorized agreement. ${ }^{138}$ Both ideas are complex and qualified, and I will not try to fully describe either of them here. What follows instead is a recharacterization of these positions designed to integrate their concerns with my own. ${ }^{139}$ To be clear, I make no claim that the recharacterization is one that either Rawls or Sunstein would endorse. What matters here is not what either of them in fact thought, but whether the concepts they used help to untangle the puzzle of substitute arguments.

Rawls despaired of achieving agreement about what he called "comprehensive doctrine" - a concept that is analogous to, although not synonymous with, what I call foundations. ${ }^{140}$ On the level of foundations and comprehensive doctrine it is impossible to make arguments that we can reasonably expect others with different views to accept. Insisting on these arguments therefore violates the requirement of reciprocity that we should expect from our fellow citizens. ${ }^{141}$ In the vocabulary that I have used, but that Rawls himself would probably reject, we might say that the arguments are not reasonable because they are substitutes for the "because I said so" assertion at the bottom of the reasoning chain.

137 See RAWLS, POLITICAL LIBERALISM, supra, note $\mathrm{xx}$, at 132-72.

138 See CASS R. SUNSTEIN, ONE CASE AT A TIME: JUDICIAL MINIMALISM ON THE SUPREME COURT (1999).

139 For example, in what follows, I make no effort to take into account Rawls' "proviso," which permits resort to comprehensive doctrine in limited circumstances, see RAWLS, POLITICAL LIBERALISM, supra, note xx, at 453, 462-466; his exception for "witnessing," see id. at 466 n. 57; or his complex views about the circumstances under which the public reason obligation takes hold. See id., at 214.

140 See id. at 12-13, 174-76, 374-81.

141 See id. at 442, 483. 
It does not follow, however, that we are doomed to a war of all against all. We might avoid arguments at the foundational level by utilizing substitute arguments at the structural level. Here, Rawls' conceptions of an overlapping consensus and public reason take hold. Even when people are motivated by conflicting foundational arguments or comprehensive doctrines, they might all endorse what Rawls calls a political conception of justice. Put differently, their conclusions might overlap at the level of structure. For example, Christians, utilitarians, and virtue theorists might all agree - albeit for different and even conflicting reasons on the basic structure of the political order. By replacing foundational argument with structural substitutes, we can achieve a just peace. ${ }^{142}$

One might recharacterize Sunstein's project as applying the same analysis on the level of specificity. Instead of focusing on societal structure, Sunstein's principal concern is judicial decision making in individual cases. A judge deciding such a case might announce and defend a broad principle with large spill-over effects, but Sunstein thinks that trying to achieve consensus on such a principle is often a mistake. If the judge writes a narrower "undertheorized," decision, it will be easier to achieve consensus among people who might disagree about the underlying theory. ${ }^{143}$ Moreover, avoiding spillover effects also avoids the possibility that the decision will produce unanticipated and undesirable consequences in a future case. ${ }^{144}$

Thus, both Rawls and Sunstein think - or at least can be taken to think - that we can achieve good results by adjusting the level at which arguments are made from foundations to structures (Rawls) and specifics (Sunstein). What about the mental states with which the arguments are made? Rawls endorses only nonmotivating substitutes. His argument is not that people should cynically advance arguments that they themselves do not believe, but that an overlapping consensus can be achieved among adherents to reasonable comprehensive doctrines on authentic arguments in favor of basic 
political structures. The arguments reflect positions honestly held, but they are nonetheless substitutes because they are motivated by foundational positions that, Rawls believed, should not be publicly expressed, at least by public officials on matters of basic political structure.

In contrast, Sunstein seems to endorse unconscious - perhaps the right word is "preconscious" - substitutes. He thinks that most judges lack a worked out structural or foundational theory and that this is a virtue. They are not, then, suppressing a consciously motivating argument in the fashion that Rawls favors. Instead, they content themselves with thinking about lower level outcomes. The arguments they derive might, nonetheless, be characterized as unconscious substitutes on the assumption that the more specific results are not merely random or arbitrary. Even if judges do not consciously work out the details of an overarching theory, they must have inchoate reasons why they decide cases in one fashion rather than another. Those reasons are not worked out or brought into consciousness, and Sunstein seems to think that this is a good thing. If they were conscious, judges would find it harder to suppress them in forming coalitions with others who have different reasons and harder to change course when the reasons lead to results that are undesirable.

To summarize, then, Rawls and Sunstein might be characterized as favoring substitute arguments that are nonmotivating or unconscious on the level of specifics and structure so as to avoid divisive arguments on the foundational level. What about hypocritical substitutes? Although neither Rawls nor Sunstein endorses hypocritical substitutes, one might build on their insights in a way that provides support for them.

Consider in this regard Jessica Bulman-Pozen's powerful case for what she calls "partisan federalism." ${ }^{145}$ Even a casual observer of our constitutional culture knows that federalism provides

145 Jessica Bulman-Pozen, Partisan Federalism, 127 HARV. L. REV 1077 (2014). I made a similar argument in LOUIS MICHAEL SEIDMAN, OUR UNSETTLED CONSTITUTION: A NEW DEFENSE OF CONSTITUTIONALISM AND JUDICIAL REVIEW 8-9, 56-58 (2001). 
fertile turf for hypocritical substitutes at the level of specificity. How can some conservatives who complain that Congress's Article I commerce clause power does not justify federal economic regulation also favor a broad reading of the same power to justify a federal prohibition on late-term abortions? Why do some liberals who favor federal power to regulate health insurance markets oppose federal power to control the distribution of drugs used in cases of end-of-life suicide?

Bulman-Pozen explains why these hypocritical arguments are so prevalent and advances a defense for them. On her account, federalism provides a platform for groups that are out of power on the national level from which they can advance their causes. By giving losers some power on the local level and a base from which they can organize with the hope of achieving future power on the national level, federalism promotes civic peace and attachment to the polity among people who profoundly disagree. ${ }^{146}$

A natural consequence of these arrangements is that actors will regularly advance hypocritical substitute arguments at the level of specificity. Republicans out of power on the national level will make federalism arguments until, but only until, they gain national power, and Democrats will do the same. Of course, Bulman-Pozen uses different vocabulary, but her insight suggests that there is a strong, authentic argument on the level of structure for a system that encourages hypocritical substitutes on the level of specificity.

Debate about federalism provides a particularly vivid example of this phenomenon, but the point is generalizable. Consider the occurrence of what Jack Balkan has called "ideological drift." ${ }^{147}$ Arguments for constitutional rights, once associated with one side of the political spectrum over time drift to the other side. Putative free speech rights of picketers provide a recent and powerful

$146 \quad$ See id. at 1122-35.

147 Jack Balkin, Ideological Drift and the Struggle over Meaning, 25 CONN. L. REV. 869 (1992-93). 
example. ${ }^{148}$ When picketers were striking union members or civil rights and antiwar protesters, liberals defended their activities as constitutionally protected speech, while conservatives attacked the same activities as barely disguised coercion. Now that the picketers are pro-life protestors demonstrating at abortion clinics, many people have changed sides. ${ }^{149}$

Similar shifts are apparent regarding more general free speech principles. Liberals favored first amendment rights in an era when they protected unpopular leftist and minority groups. ${ }^{150}$ Conservatives favor them in an era when they protect commercial and corporate speech. ${ }^{151}$ Nor is the phenomenon limited to federalism and free speech issues. In the late nineteenth and early twentieth centuries, conservatives seized on due process and equal protection arguments to limit the reach of redistributive legislation. ${ }^{152}$ More recently, liberals have used the same provisions to support reproductive rights and the claims of racial minorities. ${ }^{153}$ And on the most general level, shifting stances regarding judicial activism and restraint plainly correspond to perceptions regarding whether liberals or conservatives enjoy a Supreme Court majority.

Shifts of this sort are often derided as "unprincipled," but that label fails to capture what is actually going on. The shifts are motivated by deep principle - by commitments to foundational ideas about social justice. It would be more accurate to say that the shifts are produced by substitution at the

148 See generally, Catherine Fisk \& Jessica Rutter, Labor Protest under the New First Amendment, 36 BERKELEY L. J. OF EMP. \& LAB. L. 277 (2015).

149 Compare, e.g., Thornhill v. Alabama, 308 U.S. 547 (1939) (labor picketing) with McCullen v. Coakley, 134 S. Ct. 2518 (2014) (abortion picketing).

150 See, e.g., Dennis v. United States, 341 U.S. 494, 581 (1951) (Douglas, J., dissenting) (Communist Party); Brown v. Louisiana, 383 U.S. 131 (1966) (civil rights protestors).

151 See, e.g., Lorillard Tobacco Co. v. Reilly, 533 U.S. 525 (2001) (invalidating limit on cigarette advertising); Citizens United v. Federal Election Comm., 558 U.S. 310 (invalidating limit on corporate political speech). 152 See, e.g., Cotting v. Godard, 1183 U.S. 79 (1901) (equal protection); Lochner v. New York, 198 U.S. 45 (1905) (due process).

153 See, e.g., Roe v. Wade, 410 U.S. 113 (1973) (reproductive rights); Brown v. Board of Education, 347 U.S. 483 (1954) (rights of racial minorities). 
structural and specific levels. Ideological drift is caused by the reluctance of advocates to advance foundational argument and the necessary resort to structural and specific substitutes in their place.

The logic of Bowman-Pozen's argument suggests that we should celebrate substitutions of this sort. In the spirit of Rawls, we might say that the Constitution as a whole is designed to provide people in a radically diverse polity with a sufficient stake in the system such that even when they lose particular battles, they have an incentive to maintain their allegiance. It does so by providing a vocabulary that is sufficiently ambiguous and encompassing to allow all sides to plausibly claim that the positions they actually hold for nonconstitutional reasons are mandated by constitutional text. ${ }^{154}$ Put more directly, one might say that, the central purpose of the Constitution itself is to facilitate hypocritical substitution.

This argument, in turn, provides an explanation for our ambivalence about substitute arguments. If the position is correct, then we cannot foreswear substitution because resort to substitutes respects our foundational differences. It makes it possible for people to form a political community in the face of deep differences in values and beliefs. Ironically, the positive effects of substitution may be most important in cases where the authentic arguments are most disreputable. For example, even if some arguments about crime, education, and public assistance are motivated by racism, this may be the price we pay for having removed direct appeals to racism from the public square. For just this reason, though, we cannot candidly embrace substitution. Substitute arguments defuse potentially explosive disagreement about foundations only because we appear to be arguing about something else. A concession that, say, disputes about the first amendment rights of picketers is really about abortion rights would reignite the very conflagration we are trying to extinguish. Substitution achieves its ends only if we deny and condemn it even as we embrace it. 
It turns out, then, that there is much that is attractive about substitution. But even though it may play a crucial role, we should not ignore the costs that it imposes. Pervasive substitution produces a world where nothing is as it seems. Vast rhetorical space in our constitutional culture is occupied by shadow-play. People who seem to be engaging about issues of constitutional doctrine talk past each other, mouthing arguments about, say, original public meaning or the binding force of precedent or the importance of tradition that are deeply beside the point. No one mentions the actual topic of conversation because to do so ultimately leads to the concession that what is at stake is power rather than reason. The result is the huge and ever-expanding argumentative wasteland that is constitutional scholarship, doctrine, and popular discussion. On this account, much or all of what passes for serious debate amounts to an effort to change the subject. If nothing else, we need an accounting for all the paper wasted in the half-successful effort to hide from ourselves and others what is really at stake.

This concern weighs heavily for academics, judges, and lawyers who devote their lives to arguing about constitutional law. It is understandably less important to ordinary people engaged in more productive lines of work. More concerning for the rest of us is the prospect of giving up on the ideal of achieving an authentic deliberative democracy. ${ }^{155}$ In its worked out form, this ideal, too, smells of the lamp. Still, the notion that our disputes can be resolved by law and reason without resort to naked power is part of the usually unspoken but nonetheless powerful justificatory ideology of self-rule that binds ordinary Americans together. But if the argument I have made above is correct, then the alternative to naked power is not authentic deliberation, but manipulation through substitution. ${ }^{156}$

155 See, e.g., Gerry Mackie, “All Men Are Liars: Is Democracy Meaningless?” in DELIBERATIVE DEMOCRACY 73 (Jon Elster, ed. 1998) (arguing against social choice theorists for the possibility of authentic deliberative democracy). See generally Joshua Cohen, Deliberation and Democratic Legitimacy, in DELIBERATIVE DEMOCRACY: ESSAYS ON REASN AND POLITICS 67 (James Bohman \& William Rehg eds. 1997) ; Robert Post, Participatory Democracy and Freedom of Speech, 97 VA. L. REV. 477 (2011) ; AMY GUTMANN \& DENNIS THOMPSON, WHY DELIBERATIVE DEMOCRACY (2004).

156 Cf. Cass R. Sunstein, Fifty Shades of Manipulation (unpublished manuscript on file with author) (defining "manipulation" as "an effort to influence people's choices ... [when] it does not sufficiently engage or appeal to 
Similarly, consider Seana Shiffrin's powerful defense of what she calls a "thinker based" approach to freedom of speech. ${ }^{157}$ Shiffrin defends our free speech regime on the ground that we must "preserve meaningful opportunities for the proper realization of our moral agency." 158 This claim, in turn, rests on the desirability of protecting "the reliability and trustworthiness of communication as a window into another's minds." ${ }^{59}$ On her view "[t]o abridge freedom of speech is, to a significant extent, to isolate thinkers from one another." 160

Shiffrin presents an appealing vision of what freedom of speech might be like under a hypothetical set of circumstances. But what if, under our present, real circumstances, speech about our basic rules of governance and political commitments is systematically unreliable and untrustworthy? What if a true "window into another's mind" would rend the social fabric? Shiffrin's views are incompatible with a constitutional order that crucially rests on pervasive substitution for stability and cohesion.

Of course, the ideology of discursive honesty and deliberation, if not its reality, might be preserved if we manage to fool ourselves with substitution, but the deception can never be fully effective. Constitutional advocates have a strong incentive to point out the hypocrisies, inconsistencies, and double-standards that their opponents resort to. The result is that a large part of constitutional argumentation is devoted to tearing down the very justificatory ideology that the rest of it is designed to

their capacity for reflection and deliberation.") (emphasis in original). On Sunstein's account, manipulation causes a problem "when choosers justly complain that because of the actions of a manipulator, they have not, in a sense, had a fair chance to make a decision on their own. Often the distinguishing mark of manipulation is a justified sense of ex post betrayal." Id. See also JOSEPH RAZ, THE MORALITY OF FREEDOM 378 (1986) (arguing that "[m]anipulation ... perverts the way that a person reaches decisions, forms preferences or adopts goals" and even when the consequences are negligible, symbolically "express[es] disregard or even contempt" for the manipulated individual.)

157 See SEANA V. SHIFFRIN, SPEECH MATTERS 79-113 (2014).

$158 \quad$ Id., at 2.

159 Id.

160 Id. 
preserve. Everyone pretends to be making authentic arguments, while everyone accuses everyone else of using unprincipled substitutes.

Eventually, ordinary people begin to catch on. The bitter fact that "everyone is doing it" begins to seep into popular consciousness. The result is the kind of disillusionment and cynicism that marks so much contemporary public reaction to constitutional law. ${ }^{161}$ Moreover, because people are better able to recognize substitution by others than their own substitution, the disillusion is coupled with anger at political opponents. The disillusion and anger, in turn, leads to a suspicion that perhaps naked power really is at the base of our polity, and the sense that opponents must therefore be demolished rather than reasoned with. In short, there is a risk that substitution will fail to achieve its central goal.

I do not mean to suggest that the risk will be fully realized. The country has survived for a long time in the netherworld of half-believed, imaginary ideals. Perhaps the ideals seem more vulnerable now than they did in the past, but, absent external shocks, there is no reason to think that our political culture will completely unravel.

Even if things go on much as they always have, though, the picture I have painted is far from pretty. Can we do better? The next section discusses that possibility.

\section{Imagining a World without Substitutes}

If the argument I have made is correct, then all of constitutional law amounts to is a giant system of substitution. As explained in Part II B 2, the reasons advanced for the constitutional structures utilized to decide individual cases are substitutes for the nonconstitutional reasons supporting those

161 See pp xx, supra; David E. Pozen, Constitutional Bad Faith (unpublished manuscript on file with author) (noting that "insinuations of bad faith are not exceptional but pervasive in American constitutional discourse ... [and] has taken center stage in constitutional culture.") 
decisions. ${ }^{162}$ As explained in Part III B, these structures, in turn serve to obscure the fact that the Constitution's ultimate purpose is to avoid foundational arguments about questions that arguments cannot resolve. ${ }^{163}$ To combine the points and state them more generally, what constitutional argument amounts to is a struggle to seize control of the national narrative so as to advance controversial and nonconstitutional political and philosophical projects under the cloak of supposedly uncontroversial constitutional principle.

All substitution is problematic, but constitutional substitution of this sort is especially pernicious. As a matter of social fact, it is currently unacceptable to claim that the Constitution is evil or that it should be disobeyed. A claim that a particular statute or policy is unconstitutional is therefore authoritarian in the sense that it is designed to shut down argument without engaging the merits. When this move works, it takes issues off the table that should be fairly contestable. Even when it does not work, it raises the temperature of discussion and, often, diverts it into a swamp of irrelevant substitution relating to ancient text and fine points of constitutional doctrine.

Can we imagine a world where there was no substitution of this sort? Before exploring what such a world would look like, it is important to acknowledge the limits of this project. What follows is an exercise in utopian political theory. I provide no strategy for getting from here to there, no account of the circumstances that might produce the changes that I describe, no claim that such changes are likely. Of course, we need to address these important questions, but first we need to think about whether this world is even a conceptual possibility and, if so, whether it is a desirable one.

162 See pp xx, supra.

163 See $\mathrm{pp} \mathrm{xx}$, supra. 
It is relatively easy to imagine a world with much less substitution if power devolved to smaller units united by a common foundational theory. If all people agreed about foundations, then there would be less need to resort to power and deception to control the people who disagreed. ${ }^{164}$

It does not follow that we could completely eliminate substitution. As discussed above, substitution is built into the role morality of practicing lawyers. Unless we are also to imagine a transformation of the adversary system, the phenomenon would continue to exist in that sphere. Moreover, even if there were shared foundations, individuals will still disagree about the structural or specific implications of their foundational agreement. At least, though, everyone would have the same starting point. Strands of classical republican theory ${ }^{165}$ as well as modern political theories that advocate localism ${ }^{166}$ or multiculturalism ${ }^{167}$ are grounded in such a vision.

There are nonetheless well-known and serious conceptual problems with realizing it. Respect for local, relatively homogeneous groups requires drawing lines to define the groups in question. This line drawing, in turn, presupposes an unchallengable decision maker who is ceded the power to exclude and include. In the absence of substitute arguments, why would dissident subgroups with contested claims to membership in the larger group accept the decision maker's judgment?

Even if there were a way to avoid intra-group squabbling, there is bound to be conflict between groups. No group will concede power to resolve these disputes to a rival group, so there would have to be some larger organization to resolve the conflict - a necessity that pushes us back toward the larger and more heterogeneous political grouping that we were trying to avoid.

164 See, e.g., Brutus, To the Citizens of the State of New York, in 2 the complete Anti-federalist 368-72 (HERBERT J. STORING, ed., 1981) (arguing for a small republic). Cf. XIX COLLECTED WORKS OF JOHN STUART MILL 547 (J.M ROBSON, ed.) (1977) ("Free institutions are next to impossible in a country made up of different nationalities. Among a people without fellow-feeling, especially if they read and speak different languages, the united public opinion, necessary to the working of representative government, cannot exist.")

165 See note $\mathrm{xx}$, supra.

166 See, e.g., Roderick M. Hills, Jr., Romancing the Town: Why We (Still) Need a Democratic Defense of City Power, 93 HARV L. REV. 2009 (2000).

167 See, e.g., WILL KYMLICKA, MULTICULTURAL CITIZENSHIP: A LIBERAL THEORY OF MINORITY RIGHTS 6-9 (1996). 
Finally, there are real questions whether the game is worth the candle. Small political units give up the advantages of coordination and diversity that mark modern society. Even on the level of utopian theory, it is not clear that these sacrifices are worth it.

A closely related strategy, again with strong republican roots, attempts to inculcate common foundational ideas in a larger polity. Education, symbolism, propaganda, and suppression of dissident speech and religion might, at least in theory, accomplish these goals. ${ }^{168}$ No doubt, civil libertarians will have qualms about this approach. In his impassioned dissent in West Virginia Board of Education v. Barnette, ${ }^{169}$ Justice Felix Frankfurter argued that compelled adherence to patriotic symbols was necessary to maintain national unity, but most modern observers think that Justice Robert Jackson had the better of the argument when he asserted that "[i]f there is any fixed star in our constitutional constellation, it is that no official, high or petty, can prescribe what shall be orthodox in politics, nationalism, religion, or other matters of opinion or force citizens to confess by word or act their faith therein." 170

Even if one puts aside these qualms and sides with Frankfurter, we are not done with the problem of substitution. As Frankfurter himself understood, substitute arguments play an important role in establishing the habit of consent that he thought it necessary to inculcate. Thus, reverence for the flag as a symbol of national unity stands as a substitute for conflicting substantive views and values that, if openly expressed, would doubtless trigger dissent. Gaining acquiescence is no easy task if the victor constantly rubs the nose of the vanquished in the stench of defeat. Even if only half-believed, a substitute that the vanquished can understand and accept is better than the bitter truth of subjugation.

168 See, e.g., Steve G. Gey, The Unfortunate Revival of Civic Republicanism, 141 U. PA. L. REV. 801 (1993) (noting republican emphasis on inculcating common culture and tension between republicanism and respect for civil liberties).

169319 U.S. $624,654-58$ (Frankfurter, J., dissenting).

170 Id., at 642. 
Substitution may therefore be a necessary condition to the creation of the kind of national unity that, supposedly, makes substitution unnecessary.

If there is to be a world without substitutes, then, it must come about because the vanquished understands and accepts his defeat. What conditions would promote this acceptance? If the victor has and can credibly threaten overwhelming force or complete breakdown of civil order, then it might make sense for the vanquished reluctantly to accede to the status quo even if he perceives it as deeply evil. Anyone who has witnessed the Syrian civil war can appreciate the logic of this stance. It requires no substitution to understand that, bad as the Assad regime is, it is better than the death, pain, and human misery necessary to dislodge it.

At this point, we have no doubt moved away from the domain of utopian theory and into the dystopian. The Assad "solution" evokes Madison's famous worry that getting rid of the oxygen that fuels a conflagration also eliminates the air that allows freedom to breathe. ${ }^{171}$ Yet it is a mistake to dismiss the solution too quickly. It is not as if the elimination of force will eliminate the distinction between victor and vanquished. In a world where there is disagreement about foundations, all sides cannot prevail. Either victory will be secured by force or it will be secured by the false consent of substitution. Substitution, when it works, avoids overt humiliation, and there is something to be said for that. ${ }^{172}$ Still, one might suppose that it is in some sense better for the conqueror to be honest with the vanquished, and for the vanquished to understand the depths of his defeat. ${ }^{173}$

Is there a way out of this dark, Manichean dilemma? A familiar strain in American political thought seeks to avoid substitution by grounding consent in prosperity rather than power. On this view,

171 See The Federalist No. 10, at 49 (James Madison) (Lawrence Goldman, ed. 2008) ("But it could not be less folly to abolish liberty, which is essential to political life, because it nourishes faction, than it would be to wish the annihilation of air, which is essential to animal life, because it imparts to fire its destructive agency").

$172 \quad$ Cf. Cass R. Sunstein, Fifty Shades of Manipulation, (unpublished manuscript on file with author) (noting that "[f]rom a welfarist point of view ... [s]ome people can benefit (a great deal) from being manipulated.") 173 See id. (noting that from a deontological point of view, objections to manipulation "reflect a sense that people are not being treated respectfully" and that "[t]heir own capacities - to assess, to weigh, to judge - are not being given appropriate deference." 
Americans have been spared the periodic bloodbaths that punctuate European history by eschewing arguments about fundamentals in favor of a shared commitment to material welfare. ${ }^{174}$ For our purposes, we can put to one side the question whether this solution accurately captures the American experience. Whether it does or not, it provides a possible template for a more attractive hypothetical polity that might prosper without substitutes.

In such a world, there would once again be winners and losers - how could there not be? We might imagine, for example, that the state was officially "white" or "Christian" or "male" or "straight" and that people not fortunate enough to fit into these categories were in some sense second-class citizens. There would be no effort to sugar-coat this status, no pretense of universalism, no thinly or thickly veiled substitution that attempted to cloak what was really going on. The losers would nonetheless grudgingly accept their status because they have been bought off by the prospect of a comfortable life.

Could such a society successfully function? Its survival would depend upon two conditions that are not always present: material prosperity and the absence of ideological commitment strong enough to motivate actions that risk such prosperity. As soon as these conditions no longer pertained, those in power would almost certainly resort to substitution to maintain the status quo. Indeed, there is no need to speculate about this tendency. In the real United States, where a theology of affluence supposedly holds us together, substitution nonetheless reigns.

If we are to imagine a polity without substitution, then, we must move from mere utopianism to a truly millennial vision - a move that many otherwise tolerant readers will no doubt be unwilling to make. We must imagine a country where people feel bonds of fellowship, solidarity, and affection that

174 See, e.g., DANIEL J. BOORSTIN, THE GENIUS OF AMERICAN POLITICS 2-30 (1958); LOUIS HARTZ, THE LIBERAL TRADITION IN AMERICA: AN INTERPRETATION OF AMERICAN POLITICAL THOUGHT SINCE THE REVOLUTION 3-27 (1991). 
rest on no foundation at all other than the instinctive pull of human connection. These bonds would have to be so strong that they would transcend and overpower otherwise deeply divisive and strongly held ideological and philosophical disagreement. In such a world, there would be no winners and losers because everyone would have completely interlocking utility functions. Substitution would be unnecessary because every person would have fully accepted every other person for who she was; people would value rather than fear the different views that others held. ${ }^{175}$

Millennial imagining of this sort yields a deep irony for those committed to the classical republican project of deliberative democracy. As I have argued above, ${ }^{176}$ commitment to authentic deliberation is inconsistent with widespread substitution. Substitution undermines the openness and honest joint pursuit of the common good at the heart of republicanism. But it turns out that the elimination of substitution is also inconsistent with deliberative democracy. To eliminate substitution is to eliminate politics itself, at least if politics is conceived of as struggle over issues that divide us. In a world where substitution is unnecessary there is nothing that divides us and, so, no need for politics.

Can we imagine such a world? We occasionally catch glimpses of it in rare moments of unity and solidarity. Those of us who cannot (yet?) imagine it as a permanent state of affairs will have to make due with a less satisfying compromise. A polity where power, deception, and alienation do not exist is not in the cards. Still, there are questions of what kind and of more and less. Here, I suggest two reforms that might, at least, eliminate some of the worst features of substitution. ${ }^{177}$

175 Strands of Critical Legal Studies have embraced this ideal. See, e.g., Peter Gabel, Critical Legal Studies as a Spiritual Practice, 36 PEPP. L. REV. 515, 532 (2009) (arguing for "morally grounded reflection anchored in the common effort to realize the values of love, compassion, and mutual concern and well-being").

176 See $\mathrm{pp} x \mathrm{x}$, supra.

177 The reforms, and the arguments for them, are spelled out in greater detail in LOUIS MICHAEL SEIDMAN, OUR UNSETTLED CONSTITUTION: A NEW DEFENSE OF CONSTITUTIONALISM AND JUDICIAL REVIEW (2001) and LOUIS MICHAEL SEIDMAN, ON CONSTITUTIONAL DISOBEDIENCE (2013). 
First, constitutional law might be reconceived in a less authoritarian light. Instead of a set of commands that required action, we might think of it as a providing a common rhetoric that allows us to express our different views. As so conceived, constitutional argument would still substitute for the real basis of our opinions, but the substitution would have a different function. Substitution can be manipulative when it hides the true basis for decision, but a softer version of merely nonmotivating substitution can actually build community. As I have argued above, ${ }^{178}$ the effort to explain one's own position in a vocabulary that one's opponents can understand might create genuine empathic connection. Even if the effort does not persuade, it might at least soften the hard edge of disagreement.

This version of constitutionalism is attractive, but it gives up on the settling function of constitutional law. A common rhetoric does not dictate common conclusions and empathic connection does not necessarily produce agreement. If I am right that totally doing away with substitution requires an unlikely millennial transformation and that we need some form of resolution of social disputes, then something will have to substitute for this substitute. But here, the second possibility takes hold. Constitutional law is substitute argument, but it is not the only form of substitution. For example, one can imagine resort to arguments from tradition, from inertia, from commonly held intermediate premises, from instrumental rationality, or from practical reason as serving a settling function.

Often - perhaps always - these arguments will also be substitutes. This side of paradise, we are just not going to have unmediated and unalienated access to each other. But the substitution would be less pernicious because less authoritarian. As things currently stand, people can argue about what the Constitution means, but they cannot argue about whether it should be treated as authoritative. Other

178 See pp xx, supra. 
candidates for settlement are more controversial and, therefore, lack the capacity to shut down discussion.

Ironically, even resort to foundations - the very thing that constitutionalism is supposed to avoid - might be less destructive. Given the current status of the Constitution, if you say that the Affordable Care Act is unconstitutional, then I must either give up on my support for it or travel down the rabbit hole of textual and doctrinal substitution to prove you wrong. But if you say that the Affordable Care Act violates the principles articulated by John Locke, I have another possibility: I can deny that Lockean principles should provide the criteria under which our dispute should be resolved. True, if Locke's political theory is at the bottom of the argumentative chain, we are not going to be able to resolve our dispute by further rational discourse. But neither will the discussion be ended by resort to a standard that everyone is obligated to accept as authoritative.

This irony, in turn, gives rise to another one: The problems with constitutional substitution are mostly a product of the iconic status of the Constitution. ${ }^{179}$ If my argument against constitution worship were accepted, the Constitution would lose its iconic status and, so, the problems with constitutional substitution would be less pressing.

Can we imagine a world where the argument was widely accepted? Imagining such a world is unquestionably a stretch. No doubt, we would need more forbearance, solidarity, and tolerance of uncertainty than is common today. Still, while there are no countries that function without some form

179 Cf. David E. Pozen, Constitutional Bad Faith (unpublished manuscript on file with author) (arguing that "belief in the Constitution as America's 'civil religion' not only fails to ward off but actively sustains a culture of interpretive bad faith.") 
of substitution, there are many that seem function just fine without substitution rooted in an iconic Constitution. ${ }^{180}$

There are no deep reason rooted in human nature or history why we could not join them. To do so, though, we will first have to overcome some of the cynicism and alienation that constitutional substitution itself engenders.

180 See, e.g., Thomas C. Grey, The Constitution as Scripture, 37 STAN. L. REV. 1, 17 (1984) (noting that no other country treats its constitution as a sacred symbol). 